\title{
From new imported inputs to new exported products. Firm-level evidence from Sweden
}

Article

Accepted Version

Creative Commons: Attribution-Noncommercial-No Derivative Works 4.0

Castellani, D. and Fassio, C. (2019) From new imported inputs to new exported products. Firm-level evidence from Sweden. Research Policy, 48 (1). pp. 322-338. ISSN 0048-7333 doi: https://doi.org/10.1016/j.respol.2018.08.021 Available at https://centaur.reading.ac.uk/79118/

It is advisable to refer to the publisher's version if you intend to cite from the work. See Guidance on citing.

To link to this article DOI: http://dx.doi.org/10.1016/j.respol.2018.08.021

Publisher: Elsevier

All outputs in CentAUR are protected by Intellectual Property Rights law, including copyright law. Copyright and IPR is retained by the creators or other copyright holders. Terms and conditions for use of this material are defined in the End User Agreement.

www.reading.ac.uk/centaur

\section{CentAUR}


Central Archive at the University of Reading

Reading's research outputs online 
Policy

Elsevier Editorial System(tm) for Research

Manuscript Draft

Manuscript Number: RESPOL-D-17-00990R2

Title: From new imported inputs to new exported products. Firm-level evidence from Sweden

Article Type: Research paper

Keywords: importing, exporting, technology upgrading, Sweden

Corresponding Author: Dr. claudio Fassio, doctorate

Corresponding Author's Institution: University of Lund

First Author: claudio Fassio, doctorate

Order of Authors: claudio Fassio, doctorate; Davide Castellani

Abstract: This paper investigates the determinants of the propensity of firms to export new products, and focuses on the role of new imported inputs. Importing offers access to new technologies and better combination of inputs that can lead to new or improved products for the export markets. Based on a sample of more than 14,000 Swedish manufacturing firms over the period 2001-2012, we show that importing new inputs is a key determinant of firms' propensity to add new products to their export portfolio, even after controlling for multinationality, patenting activity, productivity and a number of other firm characteristics. This is mainly due to the import of new intermediate inputs and it is stronger for smaller firms. 


\title{
Title: \\ From new imported inputs to new exported products. Firm-level evidence from Sweden
}

\author{
Author details: \\ Davide Castellani \\ Henley Business School, University of Reading \\ davide.castellani@henley.ac.uk \\ Claudio Fassio \\ Lund School of Economics and Management, Lund University \\ \& CIRCLE, Lund University \\ claudio.fassio@fek.lu.se
}




\section{From new imported inputs to new exported products. Firm-level evidence from Sweden}

\section{Research highlights}

We study the determinants of the propensity of firms to export new products

We focus on the role of new imported inputs.

Importing new inputs is a key determinant of the introduction of new exported products

Import of new intermediate inputs has a stronger effect than other types of imports

The effect is stronger for small firms. 


\title{
From new imported inputs to new exported products. Firm-level evidence from Sweden
}

\begin{abstract}
This paper investigates the determinants of the propensity of firms to export new products, and focuses on the role of new imported inputs. Importing offers access to new technologies and better combination of inputs that can lead to new or improved products for the export markets. Based on a sample of more than 14,000 Swedish manufacturing firms over the period 2001-2012, we show that importing new inputs is a key determinant of firms' propensity to add new products to their export portfolio, even after controlling for multinationality, patenting activity, productivity and a number of other firm characteristics. This is mainly due to the import of new intermediate inputs and it is stronger for smaller firms.
\end{abstract}

Keywords: importing, exporting, technology upgrading, Sweden JEL codes: F23, O30 


\section{Introduction}

A large number of studies, starting from the seminal work of Posner (1961) and the related "technology gap" literature, highlighted the important nexus between the ability of firms to constantly introduce new products and their ultimate export success (Fagerberg, 1988; Wakelin, 1998; Basile, 2001; Cassiman et al., 2010; Dosi et al., 2015). Only through the constant introduction of new products firms can remain competitive on international markets, where rents stemming from the introduction of such new products are quickly eroded by the fast imitation of foreign competitors. Much more than firms that only operate in domestic markets, exporting firms need to constantly renew and adapt the portfolio of products that they sell abroad, by upgrading the quality of existing products, or by introducing radically new ones. In such a turbulent competitive landscape, the ability of firms to start exporting new products represents a crucial indicator of their competitiveness and ability to stay ahead of competition in international markets.

In this paper, we investigate the propensity of firms to export products that they have never exported before. This indicator is a good proxy of the ability of exporters to constantly introduce significantly new and improved products to be sold abroad. Recent studies have referred to this process as export diversification (Cirera et al. 2015), although it may well be that firms simultaneously add new products to their export portfolio, thus increasing their export diversification, but also drop existing ones, thus possibly reducing diversification. Regardless of whether introducing a new product to the export portfolio of a firm determines more or less diversification, we submit that it indicates that the firm has invested the resources necessary to render it competitive in international markets: this might correspond to a technological upgrade of an existing product, its adaptation to the requirements of foreign markets or the introduction of a completely new item. Since, according to this framework, the introduction of new exported products is an important determinant of the overall competitiveness of firms, it is crucial to identify the main drivers of their introduction. This paper focuses on the role of importing new inputs.

Importing new inputs can allow firms to benefit from technology embodied in the foreign produced capital goods or to achieve a better combination of intermediate inputs and to access a larger pool of knowledge that can lead to new or improved products for the export market. Existing empirical studies have shown that easier access to imported inputs can significantly contribute to improve the quality and scope of the product portfolio of domestic firms (Kugler and Verhoogen, 2009; Goldberg et al., 2010) and more recently to the rate of innovation (Qing and Diu, 2016). The same relationship was found also in an analysis at the sectoral level in European countries (Colantone and Crino', 2014). To the extent that imported inputs help upgrading firms' product portfolio, they can also contribute to their ability to export such products. In line with this view, recent evidence has supported the idea that imported inputs can explain the probability of firms to export, together with the more usual determinants such as firm size, innovation and productivity. Recent studies have provided detailed evidence on the links between importing and exporting activities, showing that importing inputs strongly fosters future exporting activities, as well as the scope and quality of their exported products. Evidence in this direction have been provided for countries as diverse as China (Feng et al., 2016; Xu and Mao, 2018), France (Bas and Strauss-Kahn, 2014), Italy (Lo Turco and Maggioni, 2013), Slovenia (Damijan and Kostevc, 2015), and a sample of firms from 27 Central and Eastern European countries (Aristei et al., 2013).

We use very extensive data from the population of Swedish manufacturing firms over the 2001-2012 period. By taking advantage of transaction-level data of export flows at a very disaggregated product level (8-digit CN8 classification) for each firm, we identify products 
that were added to a firm export portfolio in each year, i.e. products that were exported for the first time by a firm. Trade data is also used to identify the new products imported by a firm in each year t. We also matched these data with the register of business groups in Sweden, which allows us to identify which firms are part of multinational groups, distinguishing between groups in which the ultimate owner is a Swedish or a non-Swedish company, and we are able to control for a number of additional firm-level factors that might influence their overall ability to export new products, such as patenting activity, firm size, productivity, and capital intensity.

The results of the empirical analysis point to a positive and significant role of new imported inputs as an important factor able to foster the introduction of new exported products. This effect is larger in magnitude when firms import intermediate goods, suggesting that the main channel could be the possibility to exploit the opportunity to recombine a variety of intermediate inputs. The view that through importing activities firms are able to access technologies embodied in foreign produced capital goods finds also some support in our data, since import of capital goods is positively associated with the export of new products. Our evidence also supports the hypothesis that small and medium size enterprises (SMEs) benefit the most from the access to new imported inputs, consistently with the idea that larger firms may have also other ways to get ahold of better technologies and intermediate inputs.

The paper contributes to the literature in several ways. First our results complement the recent study by Cirera et al. (2015) on export diversification - that has stressed the role of firms' innovative efforts and their strategic positioning in the domestic market - by focussing on the role of imported inputs. Second, we highlight two main channels through which imported inputs can affect the technological competences of exporters: a variety channel and a technological upgrading channel. This allows us to interpret the higher impact of intermediate goods with respect to capital goods on the introduction of new exported products. Finally, we provide detailed evidence about the effect of imported inputs for smaller and larger firms, suggesting that especially for the former this can be a more important channel of technology upgrading.

The paper is organised as follows. Section 2 reviews the relevant literature and introduces our main hypotheses. Section 3 describes the data and provides some descriptive statistics. Section 4 lays out our econometric analysis and discusses the results. Section 5 concludes.

\section{Background literature}

\subsection{The role of new imported inputs}

In order to be able to export new products firms can either improve and upgrade the quality of their existing products or they can create brand new products that, because of their technological superiority (or because of higher cost competitiveness), are better suited for international markets. Innovative activities, such as investments in in-house product development or more formalized R\&D expenditures, are a typical way through which firms can achieve such goals. In addition, the relevant technology needed for product upgrading can often be embodied in the inputs that are used in the production processes and which need 
not to be necessarily developed internally by the firm, but can be also purchased from other firms. Accordingly, together with in-house innovative activities, access to better (or cheaper) inputs can substantially affect the efficiency of the production process, as well as the overall ability of firms to produce new products that can be competitive on international markets.

Imported inputs can foster product upgrading and innovation through two main channels. On the one hand, they allow to gain access to a larger variety of inputs. Considering the imperfect substitution between foreign and domestic inputs, imported inputs can realize the optimal configuration of inputs available both at home and abroad. By importing a wide variety of intermediate goods, which can ultimately improve firms' productivity, firms can boost their ability to introduce new and/or higher quality products, which can eventually be exported (Ethier, 1982; Halpern et al., 2015; Xu and Mao, 2018). In this perspective, importing allows firms to identify inputs that match their needs and re-combine resources in order to introduce new/improved products (Andersson and Stone, 2017). This channel of product upgrading has been documented in many recent studies, that have shown that imported inputs can have a strong positive effect on the ability of firm to start selling new products (Goldberg et al. 2010; Colantone and Crinò, 2014) and increase the quality and scope of exported products (Feng et al., 2016; Xu and Mao, 2018).

On the other hand, the role of imported inputs as a source of technology has been recognised in both aggregate (Coe and Helpman, 1995; Eaton and Kortum, 2001; Caselli and Wilson, 2004; Acharya and Keller, 2009) and firm-level studies (Kugler and Verhoogen, 2009; Halpern et al., 2015; Fan et al., 2015). In this case, the emphasis is on the fact that firms are able to acquire technology which is embodied in imported goods, and which makes them of higher quality. This is consistent with the literature on embodied technical change, according to which relevant upgrades in firms' production efficiency are made possible by the technology incorporated in the new waves of capital goods that are made available over time by competent suppliers (Antonelli, 2008). Admittedly, some studies have also highlighted that importing technology may reduce a firm's incentive to invest in innovation activities. This substitution effect, which has been evidenced using data on patenting activity of Chinese firms (Liu and Qiu, 2016), is not inconsistent with our previous arguments, that lead to the prediction that firms would introduce new products by leveraging new imported technology and combining new and old inputs. It may well be that firms reduce their patenting activity, but at the same introduce new products.

Based on the above discussion, we submit that by importing new goods firms avail themselves of new technologies and increase their recombination possibilities thus leading them to introduce new or improved products to be sold in the international markets. This leads to our first hypothesis:

Hypothesis 1: Importing new inputs positively affects the number of new exported products by a firm

\section{The type of imported goods}

Firms can import different types of products, which can entail various degrees of potential contribution in terms of the variety and quality/technology channels through which new imported inputs can lead to new exported products. We submit that the distinction between 
intermediate, capital and final goods can be used to gauge the importance of the various channels.

It is generally accepted that imported capital goods are a source of international technology transfer. Coe and Helpman (1995) Coe, Helpman, and Hoffmeister (1997), Keller (1998 and 2000) and Acharya and Keller (2009), look at R\&D spillovers conveyed through general imports of machinery, and found that the larger the share of imports from countries with large R\&D investments the larger the expected productivity gains in the importing countries. Eaton and Kortum (2000) argue that innovative activity is highly concentrated in a handful of advanced countries, which are also the major exporters of capital goods to the rest of the world. They develop a model of trade in capital goods to assess its role spreading the benefits of technological advances and relate differences in aggregate real GDP per capita to the quality of imported inputs for a sample of 34 countries. Caselli and Wilson (2004) look at disaggregated imports of various types of equipment and argue that the composition of capital has the potential to account for some of the large observed differences in TFP across countries. Barba Navaretti et al. (2004), using data on the imports of machines from the European Union by three countries in Central and Eastern Europe and three in the Southern Mediterranean between 1989 and 1997, find that embodied technologies have a positive effect on TFP.

Intermediate inputs can as well act as vehicles for international technology transfer, as they can embody significant technology (such as parts and components in the electronics industry, for example), but the literature has stressed that by increasing the variety of inputs, importing intermediates can lead to product improvements and increased export scope and quality via re-combination. Halpern et al. (2015) decompose the import effect into a quality and variety channels and find that combining imperfectly substitutable foreign and domestic varieties is responsible for about one-half of the productivity gain from imports. This finding parallels the evidence in Goldberg et al. (2010), that combining foreign and domestic intermediate inputs increased firms' product scope in India. Feng et al. (2016) find that intermediate input imports help Chinese firms to increase the scale and breadth of their participation in export markets. Also based on Chinese data, Fan and Li (2013) find that firms which increased both the number and quality of intermediate inputs, were able to increase their export prices. Similarly, Xu et al. (2016) find that the increase in Chinese firms' access to a greater variety of imported intermediate inputs can explain the product quality upgrading of these firms.

Summing up while capital goods are expected to mainly induce a technology upgrade effect, intermediate imported goods allow both for a combination of variety and technology upgrade effects. On the basis of this we put forward our second hypothesis, according to which:

Hypothesis 2: Importing new intermediate inputs has larger effect on the number of new exported products by a firm than importing new capital goods.

\section{The role of firm size}

The effect of new imported inputs on a firm's propensity to export new products might vary with firm characteristics. In particular, we believe it is relevant to investigate the role of firm size. In fact, it is most often argued that while import competition can benefit consumers, it can push small (and relatively inefficient) firms out of the market. This has sometimes been used to justify protectionist policies. However, while smaller firms may suffer more than 
larger firms the competition of foreign producers, they may also benefit from trade through the import of intermediate and capital goods. For small and medium sized firms, importing can be a particularly efficient way to boost their ability to improve and innovate on products for the export markets, and ultimately their export competitiveness. Indeed, while larger firms might possess the tangible and intangible resources to generate internally the knowledge that is necessary to upgrade their existing production processes, small firms are often more dependent on the availability of external knowledge produced by other economic actors (Feldmann, 1994; Veugelers and Cassiman, 1999), especially for the introduction of new products (Nieto and Santamaria, 2010). This knowledge can be accessed by importing intermediate goods. Small firms may benefit from imported goods in different ways. They might access relevant knowledge embodied in new imported inputs that allow them to quickly develop new products that would have otherwise required a longer time for internal development. This is especially important for exporters who might need shorter development lags in order to be successful in foreign markets, where competition is tougher. In other cases, new imported inputs might allow small firms to develop new products that they would simply not be able to develop internally, because of the lack of the necessary internal resources. On the contrary larger firms may be less dependent on arm-length access to foreign technology and variety of intermediate inputs, because they may be able to substitute it with intra-firm networks, both at home and abroad. This leads us to formulate the following hypothesis:

Hypothesis 3: Importing new goods is a more important determinant of the introduction of new exported products for smaller firms than for larger firms

\section{Data and descriptive statistics}

We take advantage of a rich dataset provided by Sweden Statistics (SCB), which allows to combine data on international trade activities of Swedish firms with information on firms' business statistics and ownership structure. Moreover, we are also able to associate patent information to each firm, through the use of a dedicated dataset of Swedish-based inventors who applied for a patent at the $\mathrm{EPO}^{1}$ : for each firm we can detect if any of their employees applied for a patent for each year in the time period considered. The trade data covers the period from 2001 to 2012, and it includes firms' product specific information on imports and exports for each year considered, as well as information on the specific sources and destinations of trade flows.

We choose to focus on manufacturing firms since our research questions apply to firms which specifically engage in the production of goods. In order to exclude self-employment and micro-firms we set the condition that firms should have at least a median of 5 employees in the years observed to be included in the dataset. ${ }^{2}$ After this first cleaning procedure we are left with a total of 14,818 individual firms active in all manufacturing sectors. The great advantage of our dataset is its extensive coverage: for each year we have an average number of approximately 11,000 firms. According to the data provided by Eurostat, in the time span considered Sweden had an average number of 12,000 active enterprises with more than 4

\footnotetext{
${ }^{1}$ Details on the construction and characteristics of these data are found in Jung and Ejermo (2014)

${ }^{2}$ This procedure excludes from our dataset 5,132 firms. Our results are robust to the inclusion of the firms with less than 5 employees, and are available from the authors upon request.
} 
employees, meaning that our dataset covers about $90 \%$ of all active manufacturing firms with 5 or more employees in Sweden in the years 2001-2012.

\subsection{The variables}

\section{Dependent variable: new exported products}

We are interested in measuring the number of products that are exported for the first time by a firm (in the period 2001-2012), as well as the number of imported products that have never been imported before by a firm (over the same period). It must be stressed that new exported products might have been produced for the domestic market also before their introduction as exported products. However, we believe that the fact that a firm starts exporting a specific product represents a meaningful fact, which might also correspond to an increase in the quality of the product itself or to a decreased cost of production. Moreover, especially for firms based in countries with a small domestic market, like Sweden, exporting a product that previously was only produced for the domestic market also means that the overall scale of production increases dramatically. For Swedish firms, the only way to scale-up their production is through exports. This suggests that, even more than in countries with a larger domestic market, innovative investments will be strongly focused on exported products, since the domestic market would not be enough to motivate the cost of such investments. ${ }^{3}$

The first problem that we face in order to identify new exported products has to do with the product classifications of traded goods changing over time, resulting in the risk that the same product might be considered new in a specific year, only because its classification code has changed. In our data, export and import products are classified according to the 8-digit Combined Nomenclature (CN8). In order to obtain a harmonized classification for the products we implement a procedure recently suggested by Van Beveren et al. (2012) which allows to obtain harmonized CN8 classifications for any specific time period considered. ${ }^{4}$ To roughly sum up how the procedure works, whenever in a specific year $t$ the homogeneous category of products $x$ is divided into different ones (say $y$ and $z$ ), the algorithm proposed by Van Beveren et al. (2012) creates an artificial category $x^{*}$ which includes products $x, y$ and $z$ for all the period considered. If instead in year $t$ a product $j$ is included in the category of products $k$, the algorithm creates a new category $k^{*}$ which always includes $j$ and $k$ products for all the period considered. As it is evident, one typical outcome of this procedure is to reduce the overall number of product categories. In our context this is not a problem since it would only imply that we lose thinner distinctions between product types, meaning that when a firm introduces a new exported product, according to the harmonized classification, the chances that this is a truly different product with respect to the ones already exported is higher.

On the basis of the harmonized $\mathrm{CN} 8$ classification we are able to identify our main variable of interest - the number of new exported products - which corresponds to the number of products that have never been exported before by a specific firm in the period covered by our

\footnotetext{
${ }^{3}$ It must be stressed that for companies based in large economies, such as the US, new exported products might not proxy the same innovative effort. In these cases, the innovative process might resemble more the productcycle model originally devised by Vernon (1966), according to which innovative products are first designed and produced for the internal market of high income economies and only later on, when the products are more mature, they are exported.

${ }^{4}$ See Van Beveren et al. (2012) for a detailed description of the procedure implemented to obtain harmonized classifications.
} 
data (2001-2012). The number of new exported products $X \_N E W$ hence corresponds to the sum of the different typologies $k$ of products $P^{X}$ that a firm $i$ exports in year $t$ and that was not exported in any period before. Formally:

$X_{-} N E W_{i t}=\sum_{k} P_{k i t}^{X}$

Where $P_{k i t-j}^{X}=0$ for all $\mathrm{j} \geq 1$

It must be stressed that by definition this measure cannot distinguish between persistent exporters who start exporting a new type of product and domestic firms who simply start to export. In both cases the products exported will be counted as new exported products. Since in this study the determinants of the decision to engage in international trade are not the main focus of our analysis, we will focus most of our empirical analyses on firms exporting in at least two consecutive years, hence on a sub-sample of the overall number of firms in our sample. In our robustness checks section, we analyse the role of importing for the decision to start exporting. ${ }^{5}$

\section{Independent variables}

New imported products

In order to identify new imported inputs we adopt a similar procedure to measure the number of imported inputs that are imported for the first time by a firm over the period 2001-2012. Just like for the case of new exported products, also new imported products might simply be inputs that a firm previously sourced locally in the national market. However, also in this case the fact that a firm decides to start importing a product from a foreign partner might indicate an increase in the quality of the product or a decrease in the cost.

The number of new imported products $I M \_N E W$ hence corresponds to the sum of the different $k$ typologies of products $P^{I M}$ that a firm $i$ imports in year $t$ and that was not imported in any period before.

$I M_{-} N E W_{i t}=\sum_{k} P_{k i t}^{I M}$

Where $P_{k i t-j}^{I M}=0$ for all $j \geq 1$

\section{Other controls}

The data allows us to introduce also a relatively rich set of controls, such as the number of employees, total investments in physical capital, labor productivity (measured as the log of value added per employee) and a dummy variable that controls whether the firm employs any inventor that has introduced at least one patent in year $t$. In Table (1) we provide detailed information about the construction of each of the variables used in our empirical analyses.

\footnotetext{
${ }^{5}$ See Castellani and Fassio (2016) for a comprehensive analysis of the determinants of the propensity to (and patterns of) export, using the same data.
} 


\section{INSERT TABLE 1 ABOUT HERE}

In addition to the measure of new exported and imported products we also build two other variables that will allow us to control for the characteristics of firms who are involved in international trade. We define the total number of the typologies of exported products in year $t$ (sometimes referred to as export scope), as well as the total number of the typologies of imported products. While new exported and imported products can be considered as flow measures, indicating the number of new exported or imported products in a specific year, these additional variables can be interpreted as stock measures, reporting the overall number of imported and exported products by an individual firm. These measures can also be considered as a proxy of the overall trade experience of each individual firm, i.e. its exposure to international markets. The higher is the involvement of firms in trade activities the lower will be the fixed costs (due for instance to information asymmetries) related to the export of a new product. The two measures of total exported and imported products are built as follows:

$$
\begin{aligned}
& T O T_{-} X_{i t}=\sum_{k} P_{k i t}^{X} \\
& T O T_{-} I M_{i t}=\sum_{k} P_{k i t}^{I M}
\end{aligned}
$$

Moreover, in line with recent evidence that highlights the important role of the variety of product-country combinations of imported inputs (Colantone and Crinò, 2014), we also build two additional variables that measure to what extent a firm relies on specific product-country combinations in its own import portfolio, since this factor might be an important determinant of the new introduction of new exported products. We first define the number of new varieties at time $t$, where a variety is defined as an imported product that is imported from $a$ specific country for the first time by an individual firm, where $P C_{k i t}$ denotes a specific product-country combination. In line with the previous set of variables above this can be considered as a flow measure:

$$
I M_{-} V A R_{i t}=\sum_{k} P C_{k i t}
$$

Where $P C_{k i t-j}=0$ for all $j \geq 1$

Then we also build a stock variable (TOT_SOURCES) that measures the total number of product-country combinations in year $t$ :

$T O T_{-} S O U R C E S_{i t}=\sum_{k} P C_{k i t}$

Together with export and import variables we also control for the ownership structure of Swedish firms, since this factor might be correlated with importing patterns. Our data allows us to distinguish, for each firm and all years in our sample, between independent firms, Swedish groups without foreign subsidiaries, Swedish groups with foreign affiliates (henceforth Swedish MNE) and foreign groups with Swedish subsidiaries (henceforth 
Foreign MNE). Firms that are part of MNEs have access to a large network of possible sources of inputs and exports may serve other units within the group. By controlling for multinationality, we are able to assess to what extent importing actually help explaining the export of new products, or if this is in fact a figment of firms being part of an MNE.

\subsection{Descriptive statistics}

In the upper panel of Table 2 we show the composition of our sample, distinguishing by level of internationalization. Firms involved in international trade account for around $65 \%$ of the all sample. This is in line with the high level of participation to international trade among Swedish firms, with respect to other European countries. ${ }^{6}$ The majority of firms engaging in international trade are two-way traders, which both import and export products. The number of firms who only export is almost twice as much the number of firms who only import.

\section{INSERT TABLE 2 ABOUT HERE}

As previously anticipated, since in this study we are not interested in what drives firms to start exporting, but rather in what allows exporters to add a new product to their export portfolio, in our baseline specification we will restrict the analysis to the firms who export both in year $\mathrm{t}$ and in year $\mathrm{t}-1$.

In the bottom panel of Table 2 we show the composition of this restricted sample. Since we need to make sure that firms exported also in the previous year we cannot use data for 2001, therefore the restricted sample includes only the years from 2002 to 2012 . This decreases the overall sample by roughly $50 \%$, so that now on average we have 5500 firms per year. Most of the firms in the restricted sample are two-way traders $(80 \%)$, while $10 \%$ only export, but do not have any import activity.

We now turn to our main variables of interest: new exported and imported products. In Table 3 we show that: in $75 \%$ of our firm-year observations a firm exported at least one new product, and in the case of imports this share decreases to $68 \%$. This means that among continuous exporters the introduction of new exported and imported products is not rare. However, they are relatively less common then the introduction of new varieties, that is combinations of either new products or new source/destination markets (respectively $85 \%$ and $72 \%$ of observations). While for large firms new imported and exported products are equally common, among small firms instead importing new products is relatively less common $(60 \% \text { versus } 70 \%)^{7}$

\footnotetext{
${ }^{6}$ As shown by Lööf and Andersson (2010) the share of Swedish firms involved in international trade among those with more than 10 employees is around $75 \%$.

${ }^{7}$ We define small and medium enterprises as those firms that during the period considered (2001-2012) have a median number of employees lower or equal to 50. While this classification differs from the usual categorizations used in the existing literature, it seems better suited for our specific dataset, which covers more than 10 years. Indeed, in such a long period firms might substantially change their size and hence risk being
} 


\section{INSERT TABLE 3 ABOUT HERE}

In Table 4 we show concrete examples of new exported products. In particular, we display the most common occurrences in the year 2006, a mid-point in the time period that we analyze. In the left panel of Table 4 we show the 5 most common newly exported products, as described by their $\mathrm{CN} 8$ classification and relative description. The most common types of new exported products among Swedish firms in 2006, exported for the first time by 105 firms, were devices related to hydraulic engineering such as maritime and waterway structures of iron or steel (CN8 code:73089010), followed by parts of machinery for bulldozers and excavators (CN8 code: 84314980 ), exported by 101 firms. The other common types of new exported products were "Parts and accessories for tractors and large motorvehicles" (77 firms), "Articles of wood" (56 firms) and "Office or school supplies made of plastics" (54 firms). These results show first of all that among new exported products there are many products with a relevant technological content (even if not necessarily high-tech products). Moreover the results are also in line with our expectations, as in most cases these are products for which Sweden is likely to have some kind of competitive advantage, due to the abundance of natural resources (forests in the case of wood producers), or to the historical excellence in specific skills (water management), or to the presence of relevant players in the specific industry (see the Volvo Construction Equipment - part of the Volvo Group - for the case of excavators and bulldozers).

\section{INSERT TABLE 4 AND FIGURE 1 ABOUT HERE}

The right panel of Table 4 instead allows to understand how the new types of exports relate to the existing export portfolio of the firms which introduced them for the first time. We report the most common types of product exported in the year 2005 among the firms that introduced a specific new exported product in 2006 . We do this because we want to avoid the risk to classify as new exported products tiny changes in the existing export portfolio of the firms, i.e. new products which do not require a high level of investment by the side of the firms. Since we adopt a relatively thin product classification (8-digits) we could face the risk that a tiny change in the export portfolio of an exporter figures as a brand new exported product. The results in Table 4 suggest that we are not likely to face this risk: with respect to the most common new exported products the types of products that firms exported in the previous years are related, but not too similar to the new typology exported. This somehow reassures as that firms with new exported products are on average really introducing new products in their export portfolio that they have never exported before. In order to ease the understanding of some of the description of the product codes reported in Table 4, in Figure 1 we show a graphical representation of one of the most common new exported products (parts of machinery for bulldozers and excavators - CN8 code: 84314980 ) and we also show which are the types of product that these firms were exporting in the previous year.

classified sometimes as small, medium or large, according to the specific year considered. Using the median number of employees over time allows us to attribute each firm to only one size category in our data. 


\section{INSERT FIGURES 2 AND 3 ABOUT HERE}

In order to further investigate the properties of new exported and imported products we plot the histogram of each of the variables in Figure 2. The two graphs show that the distribution of both types of products is extremely skewed. Symmetrically to Table 3, we can observe that about $25 \%$ of firm-year observations have zero new exported products and more than $30 \%$ have no new imported inputs. Furthermore, $22 \%$ of firms introduced only one new product and $17 \%$ imported a new product. These frequencies sharply drop as the number of products increases, and only in a handful of cases we observe more than 5 new exported or imported products. In Figure 3 we further distinguish by firms' size, using Kernel's densities. The plots show that the distribution of new exported and imported products is more skewed for small than for large firms, suggesting that among small firms the majority of firms have very small numbers of new exported and imported products.

\section{Econometric analysis and results}

\section{Methodology}

The aim of our empirical analysis is to identify the main determinants of new exported products and we are particularly interested in the role of new imported products. In order to do that with an empirical model, we need to consider the specific features of the dependent variable, which is a count variable with relatively high over-dispersion around its mean. Table 5 - which reports the descriptive statistics of the variables included in our model indeed indicates that the variance of new exported products is much higher than its mean. We then resort to the negative binomial regression method using a panel estimation technique with firm fixed effects, which is specifically suited for overdispersed dependent variables (Cameron and Trivedi, 2005). The empirical specification is hence as follows:

$$
E\left[X_{-} N E W_{i t} / x_{i t}\right]=\exp \left[\alpha \ln I M_{-} N E W_{i t-1}+\beta x_{i t-1}+\eta_{i}+\lambda_{t}+u_{i t}\right]
$$

where $X \_N E W$ indicates new exported products and $I M \_N E W$ denotes new imported inputs. Moreover $x_{i t}$ indicates a number of controls that we will introduce in our specification to account for various characteristics of the exporting firms: these include size, labour productivity, patenting activity, as well as the multinational status of the firm. Firm-specific fixed effects are indexed by $\eta_{i}$, while $\lambda_{t}$ denotes common time trends that are controlled for through the use of time dummies. Finally, $u_{i t}$ indicates firm-specific idiosyncratic shocks. Due to the properties of negative binomial regression models, expressing independent variables in logs or binary form allows to interpret the estimated coefficients as elasticities. ${ }^{8}$

\section{INSERT TABLE 5 ABOUT HERE}

\footnotetext{
${ }^{8}$ The use of negative binomial estimator with fixed effects has the downside of dropping observations for which a variable is constant overtime. In our case this amounts to 2,703 observations, i.e. $4.3 \%$ of the total estimation sample.
} 
The panel dimension of our dataset, allows us to account for the heterogeneity in the time invariant characteristics of the firm. This allows us to rule out the possibility that a generic 'quality' of firms, which can be correlated with their ability to introduce both new imports and exports, might bias our results. For what concerns time variant unobserved heterogeneity, our empirical strategy allows to account for some of it, through the use of time-varying controls such as productivity, patenting activity and multinational status. As a matter of example, innovative activities might be an important confounding factor: indeed the introduction of product or process innovations might both require the use of new imported inputs and increase the export success of new or existing products. The availability of data on patenting activity of firms allows us to partly control for this possible source of bias.

A further identification problem could be due to the fact that firms might strategically choose to import new intermediate inputs in order to be able to start exporting a new product. In order to attenuate this issue that can determine reverse causality, we lag all the independent variables by one year. If the decision to source new imported inputs is driven by the aim to start exporting a new product, using imports from the same year would exacerbate this endogeneity problem. Still, since our specification does not make use of exogenous shocks able to influence the propensity to import new inputs, some caution is necessary when interpreting our results as evidence of a causal effect.

\section{INSERT TABLE 6 ABOUT HERE}

\section{Results}

In column (1) of Table 6 we present our baseline specification, where we only include the control variables, without the variables related to import. We find that the total number of typologies of exported products $\left(T O T \_X\right)$ has a positive and significant effect on the number of new exported products, suggesting the presence of a scale-effect by which the higher the number of exported products by a firm, the higher also the number of new ones. However, since the coefficient is significantly smaller than 1 , we can detect some decreasing marginal returns. ${ }^{9}$ We also find a positive and significant effect of the number of employees (as a proxy for size), labor productivity and, with a smaller coefficient, investments in physical capital. These results basically confirm the usual hypotheses according to which larger and more productive firms are likely to be more successful on international markets. However, they add to this that larger and more productive firms are also better able to introduce new products that had never been exported before. We also control for the role of patenting activity through a dummy taking value 1 for firms who patent (and zero otherwise) and find a positive effect, but with a rather large standard error. Finally, we notice that the dummies indicating the different ownership types are never significantly different from zero. It must be stressed that in this specific fixed effect estimation the coefficient of the dummies should be interpreted as the effect of a change in the ownership type on the number of new exported

\footnotetext{
${ }^{9}$ It is worth mentioning that this also entails that it would be incorrect to use the share of new exported products as the dependent variable
} 
products. ${ }^{10}$ In column (2) we introduce a dummy for import activity (IMP) which shows a positive and significant coefficient, suggesting that starting to import generally increases the number of new exported products introduced by a firm.

In order to investigate the role of imported products, in column (3) we introduce our main variable of interest -the number of new imported products $\left(I M \_N E W\right)$ - which displays a positive and highly significant coefficient. We also notice that once we account for the number of new imported products the import dummy becomes negative and significant. This result highlights the fact that it is not importing per se which increases the chances of exporting new products, but rather the import of new products. As our results show, once accounted for new imported products, the impact of import is even negative, meaning that importing without introducing any new imported products can actually decrease the number of new exported products.

Instead, once controlled for the increase in import activity, becoming part of a foreign MNEs may actually decrease the rate of introduction of new exported products. When we introduce new imported products in our model we also find that the patent dummy is no longer significant. This is consistent with the idea that importing new products can be somewhat alternative to carrying out internal innovation activities.

In order to check whether there is a specific effect of imports that is related to the novelty of the imported products, in column (4) we augment our specification with the number of new imported variety $\left(I M \_V A R\right)$. As already illustrated above, an increase in the number of the new varieties might be either due to a new imported product that had never been imported before by a firm, or it can be due to a product that was already imported in the previous years, which in year $t$ is imported from a new source country. We find that the inclusion of the varieties induces a relative drop in the coefficient of the new imported products, which is not surprising, given the latter is a subset of the former, while the coefficient of the varieties is positive and significant. However, the coefficient associated with new imported products is more than twice as large as the coefficient of new imported varieties (a chi-squared test of equality of the two coefficients rejects at the $10 \%$ level the null hypothesis), suggesting a much stronger role of the latter for the increase of new exports. Finally, in column (5) we also introduce the total number of the different typologies of imported products (TOT_IM), as well as the total number of product-country combinations (TOT_SOURCES). We do this in order to control whether the effect of new imported products and new import varieties might catch respectively the overall scope of imported products of a firm or the overall number of possible sources of imports. Results show that the coefficient of new imported products slightly increases when we include the total number of typologies of imported products, the total number of different imported products instead displays a negative and significant sign. Since the number of new imported products is a subsample of the total number of typologies of imported inputs we interpret this coefficient as an indication that, once we account for new imported products, all the other imported inputs have actually a negative effect on the level of new exported products, similarly to the effect of importing per se, that we analyzed through the import dummy (IMP). On the contrary, the inclusion of the total number of productcountry combinations has a positive effect on the level of new exported products, but also in this case its inclusion does not change the positive and significant coefficient of new imported products.

\footnotetext{
${ }^{10}$ Indeed, estimates from a pooled cross-section regression, available from the authors, reveal a large positive coefficient for Swedish and Foreign MNE. This suggests that belonging to MNE groups is associated with new exported products, but the change in ownership is not.
} 
Summing up, we find that the propensity to introduce new products for the export market depend strongly on importing new products, and to a lesser extent to the introduction of new product-country combinations of imports. This confirms our first hypothesis $H 1$.

On the contrary we find that the overall number of typologies of imported products, as well as importing per se, do not have a positive effect on the level of new exported products.

When interpreting these results it must be stressed that, even if we control for firm-level fixed effects and a large number of time-varying firm-characteristics, our research design does not allow to identify a strong causal chain that goes from imported inputs to new exported products. In other words, we cannot exclude that firms decide to import new inputs because they aim at innovate their product portfolio. In this respect our results rather inform us that the availability of new imports is crucial for firms to trigger product upgrading and exporting. A further word of caution concerns the fact that our results do not allow to measure the import-content of the new exports. In other words, we are not able to verify to what extent the new imported inputs (especially the intermediate inputs) become part of the products that are then exported for the first time. While we find a strong association between new imported products and new exported products, we cannot exclude that the new imported products might be used for other products that were already exported or that are not even exported. ${ }^{11}$ We contend that with the available large-scale data it is not possible to achieve this level of detail, since we cannot unbundle exported products into the inputs actually used to produce them. One way to partially tackle this issue would be to check for the relatedness between new imported product and new exported products. If imported products are related to exported ones, because for example they frequently appear jointly in the product portfolio of firms, one could more confidently claim that imported products are actually used in exported products. However, the recombinant nature of innovation typically leads to unprecedented combinations of inputs and outputs, which hence would often challenge the concept of "relatedness" itself.

\section{The role of type of imported inputs}

Our Hypothesis $H 2$ suggests that it matters whether imported products are intermediate inputs or capital goods. In particular, we predict that, since new intermediate inputs are both carriers of technology and allow to produce new products via re-combination of factors of production, this category of goods should have a larger effect on the propensity to export new products. Using the Broad Economic Classification of traded goods, we are able to distinguish between imports in product categories that are classified as intermediate goods, capital goods or consumption (i.e. final) goods. With this piece of information, we can then break down the number of new imported products into the number of new imported intermediates, new imported capital goods and new imported final goods. We then include three new variables in equation (1) and check whether the impact differs across types of imported products.

The results in column (6) of Table 6 show that the coefficient of intermediate inputs is higher than the coefficient of the other types of goods: the effect of intermediate goods is almost twice that of capital goods (the null hypothesis of equality between the coefficient of

\footnotetext{
${ }^{11}$ As a matter of example, a new and cheaper intermediate import could be used in the production of products that were already exported, and the resources gained from the cheaper inputs could be dedicated to upgrading and exporting other products (for which the imports are not used).
} 
intermediate goods and capital goods is rejected at the $1 \%$ level $^{12}$ ). This confirms our hypothesis H2: while both intermediate and capital imported goods increase the ability of exporters to introduce new products, the effect of imported intermediate goods is relatively larger.

\section{INSERT TABLE 7 ABOUT HERE}

\section{The role of firm size}

In Table 7 we investigate more carefully the heterogeneity across firms in the effect of new imported inputs on the propensity to export new products. Indeed, as we have argued in the development of $H 3$, we have reasons to believe that the effect might differ substantially among smaller firms with respect to larger firms. In column (1) of Table 7 we present results obtained using the same specification of Table 6 but focusing only on firms with up to 50 employees. Interestingly, we notice that the coefficient of new imported products increases by roughly $20 \%$ with respect to the estimates of Table 6 , while the coefficient of new imported varieties decreases in size and becomes no longer significant. Also, the coefficient of the total number of sources (product combinations) increases by almost $50 \%$ with respect to the specification that included the whole sample. The statistical significance of other coefficients does not change.

Finally, in column (2) we show the results obtained when we only analyze the determinants of the propensity to export new products among larger firms (more than 50 employees). In this case, we find that instead the coefficient of new imported products decreases slightly with respect to our baseline specification and it becomes slightly smaller than the coefficient of new imported varieties, which instead increases by more than $60 \%$.

In columns (3) and (4) we test whether the differences in the coefficient between smaller and larger firms are statistically significant. We find that the coefficient associated with new imported inputs for smaller firms is $70 \%$ larger than for large firms (a test of equality of the two coefficients is rejected at $10 \%$ confidence level). This provides a confirmation of our hypothesis $H 3$.

In columns (5), (6), (7) and (8) instead we test whether the different type of imported inputs (intermediate, capital or final goods) have a different effect on new exported products among small and large firms. We find that while intermediate goods play an important role for all firms, capital goods only have a significant effect on the export of new products among small firms. The difference in coefficients for small, relative to large, firms is quite large and significant in the case of import of capital goods, while in the case of intermediate inputs is positive and non-negligible, although rather imprecisely estimated. This may reveal that for small firms, which may lack the internal resources to develop technology, importing technology embodied in capital goods can also be particularly conducive to introducing new products for the export market.

\section{INSERT TABLE 8 ABOUT HERE}

\footnotetext{
${ }^{12}$ Also the null hypothesis of equality between intermediate goods and consumer goods is rejected at the $5 \%$ level.
} 


\section{Robustness checks \\ Different product classification and pass-on-trade}

The descriptive evidence presented in Figure 1 and in Table 4 suggests that the introduction of new exported products often implies a substantial change in the type of products that are introduced in the international markets (with respect to the existing export portfolio). However, in order to double check for this we ran our econometric specification using a more aggregated product classification: instead of using the 8-digits CN8 classification we adopted the 6-digit product classification HS6. As in the case of the CN8 classification, also in this case we implement the harmonization procedure suggested by Van Beveren et al. (2012) to avoid problems related to the reclassification of products over time. In Table 3 we show some descriptive statistics that inform us about the differences between using the two different classifications. As expected, we notice that using a broader classification decreases the number of new exported and imported products: the mean number of new exported products drops from 3.51 to 2.96 while it decreases from 4.12 to 3.46 for the new imported products. This is not surprising, since some products that results as new in the CN8 classification might still be included in the same HS6 category and hence do not results as "new". In Table 8 we run our baseline specification of equation (1) using the HS6 classification for all the import and export related variables. The results are very robust: changing the product classification does not affect the estimated relationship between new imported products and new exported ones, hence confirming that our results are picking up just small changes among very similar products.

Another important issue has to do with the well-documented tendency of traders to re-export the same products that have been imported. This has been often labelled in the literature as pass-on-trade (Damijan et al., 2013). In our context this might be an extremely serious problem if not accounted for, since the recombination of imported inputs would not be the main determinant of the export of new products. Hence, we run the baseline specification in equation (1) but this time all the measures of new imported and exported products have been computed excluding any product that is simultaneously imported and exported by the same firm in a specific year. Again, the results in columns (4), (5) and (6) of Table 8 show a very stable pattern, suggesting that simply re-exporting imported products (pass-on-trade) is not a relevant driver of our relationship of interest.

\section{INSERT FIGURE 4 ABOUT HERE}

\section{Persistent exporters}

A possible limitation of our baseline specification is that we only focus on persistent exporters, since we are interested in firms that already have an export portfolio and investigate the determinants of the introduction of new products. However, our definition of persistent exporters is relatively loose, as we classify persistent exporters as those firms that have been exporting some products for at least two consecutive years (year $t$ and year $t-1$ ). It is hence important to check whether a more stringent definition of persistence in export activities (i.e. a higher number of consecutive years of export participation) affects our results. Being stricter in the definition of what is a persistent exporter might also allow us to distinguish more clearly the effect we are interested in (expanding the export portfolio with 
new products) from the effect of starting to export. For firms with only two years of export participation it might be more difficult to distinguish between these two effects. In Figure 4 we show the results obtained using different definition of persistent exporters. The figure shows the estimated coefficients obtained when we include exporters that export for 2, 3, 4 or 5 consecutive years, respectively. The top coefficient (2 years persistence) is the same coefficient displayed in Table 6 (column 5), as we still use the same definition of persistency ( 2 consecutive years). Going from top to bottom in Figure 4 we display the coefficients obtained running our baseline model, but adding one additional year of export experience at a time. Hence the estimated coefficient at the bottom of the table reports the results obtained running our estimates only on firms that export for 5 consecutive years (from time $t$ to time $t$ 5 ). The results show that the estimated coefficient is still positive and significantly different from zero at $99 \%$ confidence level. The magnitude of the coefficient decreases in size, partly due to the fact that if we include only very persistent exporters the share of large firms in our estimating sample increases. As shown in Table 7, larger firms benefit comparatively less from the import of new inputs with respect to smaller firms, hence the lower coefficient in Figure 4 is also a consequence of the different composition of the sample.

\section{INSERT TABLES 9 AND 10 ABOUT HERE}

\section{Discrete changes in new exported and imported products}

In Table 9 we check whether new imported products also affect the general propensity of firm to start exporting new products. We hence transform our dependent variable into a dummy variable equal to one if a firm introduces at least one new export in time t, and zero otherwise. The results show that the number of new imported inputs does not have a significant effect on the probability to export a new product. On the contrary the coefficient of imported varieties is positive and significantly different from zero.

As a further robustness check we substitute our continuous measures of new imported products and new imported varieties with two dummies that are equal to one if a firm introduces respectively at least one new imported product or a new imported variety. Also in this case we find that only varieties matter, but only for large firms. On the contrary, new typologies of imported products have no effect on average and they are even negative and mildly significant for large firms. The results do not change much when we use the new imported inputs and new imported varieties dummies in our original specification with the overall number of new exported products as dependent variable. Again we find no effect for new imported products and a mild effect of imported varieties. All in all, the results suggest that the relation between new imported products and new exported products operates at the intensive margin. This is somewhat consistent with the variety channel that we have discussed in Section 2: the larger the number of new imported products and the higher is the chance of finding useful recombinations that lead to new products for the export market.

\section{Export starters}

In Table 10 we also check whether new imported products allow domestic firms to start exporting. The results show that for both small and large firms this is not the case. New imported products do not display any positive effect on the probability to start exporting, and it does not matter whether we use a continuous measure of new imported inputs or a simple dummy. This suggest that the impact of new imports on the introduction of new exports only 
applies to persistent exporters, while it does not help domestic firms (or intermittent exporters) to start exporting. An interpretation of this findings is that, while imported inputs are an important determinant of the ability to renew and innovate the export portfolio of exporters, for firms that do not have export experience this channel is not sufficient to overcome the relevant fixed costs associated to the establishment of an export capacity. Our results seem to suggest that new imported inputs are better able at increasing the competitiveness of firms that are already exporting. Instead, domestic firms might lack a set of competences (such as managerial competences, for example) that are necessary to export, and which cannot be replaced only by the availability of new intermediate or capital inputs to be used for their productive processes.

\section{Concluding remarks}

This paper contributes to a fast-growing literature on the role of imported inputs for the export activity of the firm, by focusing on new exported products, that is new products that are exported for the first time by each firm. This approach provides a good proxy of the dynamism of exporting firms and of their ability to constantly renew and upgrade their existing export portfolio.

In the paper we investigate the role of an important driver of the introduction of brand new exported products: the access to new imported products. We propose that imported products can provide exporters with an additional channel of technology upgrading, which can eventually lead to start exporting new products. New imported products can embody relevant technology, to be used in the firms' productive process for the upgrade of existing products or for the introduction of brand new ones. It can also increase the variety of inputs in the productive processes of exporters, allowing for the recombination of new and existing inputs, which can lead to the introduction of new exported products.

Our empirical analysis, based on a sample of more than 14,000 Swedish manufacturing firms (representing more than $90 \%$ of the overall population of firms) over the period 2000-2012 and including a large number of firm-level controls, allows us to identify the impact of new imported products on the number of new exported products.

The results show, first of all, that importing new products is a key determinant of the introduction of new exported products, also after controlling for firm fixed-effects, productivity, patenting activities and multinational status. In particular, we find that firms' new exported products benefit from importing new types of intermediate inputs and, to a lesser extent, new capital goods. We submit that this is due to the fact that intermediate inputs allow firms to benefit both from a technology-upgrade effect, since imported intermediate inputs often embody relevant technology for the development of new products, but also from a variety effect, which allows for the recombination of existing and new inputs into new products. Furthermore, we find that smaller firms benefit more than larger firms from importing new products, and this differential effect is stronger when we consider import of capital goods. This may reveal that for small firms, which may lack the internal resources to develop their own technology, importing technology embodied in capital goods can be crucial for their ability to introduce new products for the export market.

We also find that the effect of new imported inputs operates at the intensive margin, i.e. it is not the fact that a firm starts importing a single new product that allows it to export new products, but rather the number of new imported products: more new products are imported 
and the higher is the chance of finding useful recombinations that lead to new products for the export market. In a similar way we find that the effect of new imported inputs is not able to lead domestic firms to start exporting. This suggests that differently from persistent exporters, domestic firms might lack competences (such as those in the management domain) and resources (like foreign distribution channels) that are necessary to export, and which cannot be replaced only by the availability of new imported intermediate or capital inputs to be used for their productive processes.

As a corollary to our empirical analysis it is worth mentioning that our methodology has also some limitations. First of all, the introduction of new exported products may well occur even within a granular level, such as the 8-digit product classification, and thus not be captured by data at this level of detail. Additionally, due to the lack of data on products sold in the domestic market, this paper cannot discern whether the new exported products had been already introduced in the domestic market or whether they are directly exported from the moment they are developed. The transition from domestic products to exported ones at the firm level is a relevant direction of research, which however, due to data limitation, cannot be pursued in this paper. Similarly, while our analysis allows to identify an important mechanism of technology upgrading and improved competitiveness through access to new imports, it still provides a very rough description of how this mechanism actually works inside the firms. Indeed, our empirical evidence does not allow to clearly describe the channel through which new imported products are turned into successful exports. This would require further information about what happens within the company, possibly investigating more deeply how imported inputs are actually transformed into new products and eventually exported. This can be done in different ways and we believe that the paper raises a number of interesting avenues for future research on this topic. We see at least two possible ways to understand better the technology-upgrading mechanism of new imported inputs. One way is to provide concrete examples of how this mechanism takes place within firms: this could be done through case-study analyses on exporting firms that upgraded their products through new imported inputs. This would allow to open the black box of the internal innovative firm processes through which imports are turned into new exports. Another way to investigate this phenomenon might instead rely on large scale studies like ours, using firm-level data and information about import and export types. In this respect a relevant dimension that might be explored is the relatedness of new exported products with respect to both the new imports and the existing export portfolio of firms. In the first case this would allow to identify the importcontent of new exports, i.e. to check whether the new imported inputs are actually used in the production of the new exported products. In the second case instead using the categories of relatedness might allow to check whether the role of imported inputs differs according to the direction of product innovation that exporters want to pursue: understanding whether imported inputs benefit related or unrelated export diversification might be important to fully understand their role for exporting firms. Lastly, the geographical dimension of export activities might be a relevant addition to the present study: this might for example allow to understand to what extent new imported inputs allow exporters to expand into new foreign markets.

Keeping in mind these important limitations, our results can provide interesting insights for public policies aimed at improving the overall dynamism of exporting firms. First, our results suggest that accessing new intermediate inputs allows firms to renew their export portfolio and start exporting new products. In a global context where imported goods are increasingly seen as crowding out domestic productions, and protectionists measures are invoked to safeguard domestic firms and jobs, our results instead remind us that the goal of economic 
integration is to be able to import goods that cannot be efficiently produced in the domestic economy. But in addition to the classical argument, this paper points out that restricting import, may jeopardize the ability of firms to introduce new exported products. Second, we show that the effect of imported inputs on new exported products is larger for SMEs. Since these firms are those that usually face bigger difficulties in international markets -and are often the target of export oriented policies- it is important to bear in mind, that protectionists measures may end up curtailing an important channel of technology upgrading and export success of SMEs. These implications are especially important for small economies like Sweden, where access to foreign inputs can substantially increase the possible options for exporters. It would be important to replicate these kinds of studies also for larger economies to check if the effect of new imports is still as strong as in our study.

The paper has also important implications from a management perspective. Our analysis highlights that the access to new imports is especially crucial for exporting SMEs. This suggests that the management of these types of companies should increase the attention devoted to this specific task. Small exporting firms already rely on "export managers" to manage their foreign operations. On the contrary the presence of an "import manager" (i.e. a manager responsible for sourcing internationally new inputs) is relatively less common in these types of firms. Indeed, while global sourcing and global purchasing is nowadays a fundamental part of the business activities of large multinational companies, this is not necessarily the case for SMEs, as these activities require additional resources. However, considering the evidence gathered in our study on the importance of accessing new intermediate inputs and capital goods for small and medium exporters, these companies should consider investing resources in managers specifically dedicated to strategic import decisions. Finally, since our results suggest that the contribution of imports is often related their technological content, import managers should interact with the firm's units that deal with product innovation and upgrading. 


\section{References}

Acharya, R.C., Keller, W. (2009). Technology transfer through imports, Canadian Journal of Economics, 42(4), 1411-1448

Andersson, M., Stone, T.A. (2017). Global Sourcing and Technical Efficiency: a firm-level study on the ICT industry in Sweden, Journal of Business Economics and Management, forthcoming.

Antonelli, C. (2008). Localized Technological Change. Towards the economics of complexity, Routledge, New York.

Aristei, D., Castellani, D., \& Franco, C. (2013). Firms' exporting and importing activities: is there a two-way relationship?. Review of World Economics, 149(1), 55-84.

Bandick, R, H Görg and P. Karpaty (2014), Foreign acquisitions, domestic multinationals, and R\&D. Scandinavian Journal of Economics 116(4), 1091-1115.

Bas, M., Strauss-Kahn, V. (2014). Does importing more inputs raise exports? Firm-level evidence from France. Review of World Economics, 150(2), 241-275.

Barba Navaretti, G., Schiff, M., Soloaga, I., (2004) The knowledge-content of machines: a new view on North-South trade and technology diffusion, in B. Hoekman and Beata S. Javorcik (eds.). Global Integration and Technology Transfer. Palgrave McMillan: New York .

Basile, R., (2001), Export behavior of Italian manufacturing firms over the Nineties: the role of innovation. Research Policy, 30 (8), 1185-1201.

Cameron, A. C., Trivedi, P. K., (2005). Applied microeconometrics using STATA. New York: STATA Press.

Caselli F., Wilson D.J. (2004) Importing technology. Journal of Monetary Economics, 51, $1-32$

Cassiman, B., Golovko, E. and Martínez-Ros, E., (2010), Innovation, exports and productivity. International Journal of Industrial Organization, 28(4), 372-376.

Castellani, D., \& Fassio, C. (2016). Import, Export and Multinationality. Evidence from Swedish Firms, John H Dunning Center Discussion Papers 2016-08. Henley Business School, Reading University.

Cirera, X., Marin, A., \& Markwald, R. (2015). Explaining export diversification through firm innovation decisions: The case of Brazil. Research Policy, 44(10), 1962-1973.

Coe, D. and E. Helpman (1995) International R\&D Spillovers, European Economic Review, $39,859-887$.

Coe, D., E. Helpman, and W. Hoffmaister (1997), "North South R\&D Spillovers", Economic Journal, 107, 134-149.

Colantone, I. and R. Crinò (2014). New imported inputs, new domestic products. Journal of International Economics, 92, 147-165.

Damijan, J.P., Konings, J., Polanec, S., (2013) Pass-on trade: why do firms simultaneously engage in two-way trade in the same varieties? Review of World Economics, 149(1), 85-111. 
Damijan, J. P., \& Kostevc, Č. (2015). Learning from trade through innovation. Oxford Bulletin of Economics and Statistics, 77(3), 408-436.

Dosi, G., Grazzi, M., and D. Moschella, (2015), Technology and costs in international competitiveness: From countries and sectors to firms. Research Policy, 44(10), 17951814.

Eaton J., Kortum S. (2001). "Trade in capital goods.” Europena Economic Review, 45(7): $1195-1235$.

Ethier, W. J. (1982). National and International Returns to Scale in the Modern Theory of International Trade, The American Economic Review, 72(3), 389-405

Fagerberg, J., (1988). International competitiveness. The Economic Journal, 98 (391), 355374.

Feldman, M. P. (1994) Knowledge Complementarity and Innovation, Small Business Economics, 6(5), 363-372.

Feng, L., Lie, Z., Swenson, D.L. (2016). The connection between imported intermediate inputs and exports: Evidence from Chinese firms, Journal of International Economics, $101,86-101$.

Goldberg, P. K., Khandelwal, A. K., Pavcnik, N., \& Topalova, P. (2010). Imported Intermediate Inputs and Domestic Product Growth: Evidence from India. The Quarterly Journal of Economics, 125(4), 1727-1767.

Halpern, L., Koren, M., \& Szeidl, A. (2015). Imported inputs and Productivity. The American Economic Review, 105(12), 3660-3703.

Jung, T. and O. Ejermo (2014) Demographic patterns and trends in patenting: gender, age, and education of inventors. Technological Forecasting and Social Change, 86, 110124

Keller, W. (1998), Are International R\&D Spillovers Trade Related? Analysing Spillovers among Randomly Matched Trade Pairs, European Economic Review, 42, 1469-1481.

Keller, W. (2000), Do Trade Patterns and Technology Flows Affect Productivity Growth ?, World Bank Economic Review, 14, 17-47.

Kogut, B., \& Zander, U. (1993). Knowledge of the firm and the evolutionary theory of the multinational corporation. Journal of international business studies, 24(4), 625-645.

Kugler, M., \& Verhoogen, E. (2009). Plants and imported inputs: New facts and an interpretation. The American Economic Review, 99(2), 501-507.

Liu Q., Qiu L. (2016) Intermediate input imports and innovations: Evidence from Chinese firms' patent filings, Journal of International Economics, 103, 166-183.

Lo Turco, A., \& Maggioni, D. (2013). On the role of imports in enhancing manufacturing exports. The World Economy, 36(1), 93-120.

Lööf, H., \& Andersson, M. (2010). Imports, Productivity and Origin Markets: The Role of Knowledge-intensive Economies. The World Economy, 33(3), 458-481.

Nieto, M. J. and Santamaría, L. (2010) Technological Collaboration: Bridging the Innovation Gap between Small and Large Firms, Journal of Small Business Management, 48(1), 44-69. 
Van Beveren, I., A. B. Bernard and H. Vandenbussche (2012). Concording EU Trade and Production Data over Time. NBER Working Paper Series, num. 18604.

Veugelers, R., Cassiman, B. (1999) Make and buy in innovation strategies: evidence from Belgian manufacturing firms, Research Policy, 28(1), 63-80.

$\mathrm{Xu}, \mathrm{J}$. , and Mao, Q., (2018) On the relationship between intermediate input imports and export quality in China, forthcoming on Economics of Transitions. https://doi.org/10.1111/ecot.12155

Wakelin, K., (1998), Innovation and export behaviour at the firm level. Research Policy, 26(7), 829-841. 
Figure 1. Graphic presentation of one of the new exported products (CN8: 84314980) of Table 5

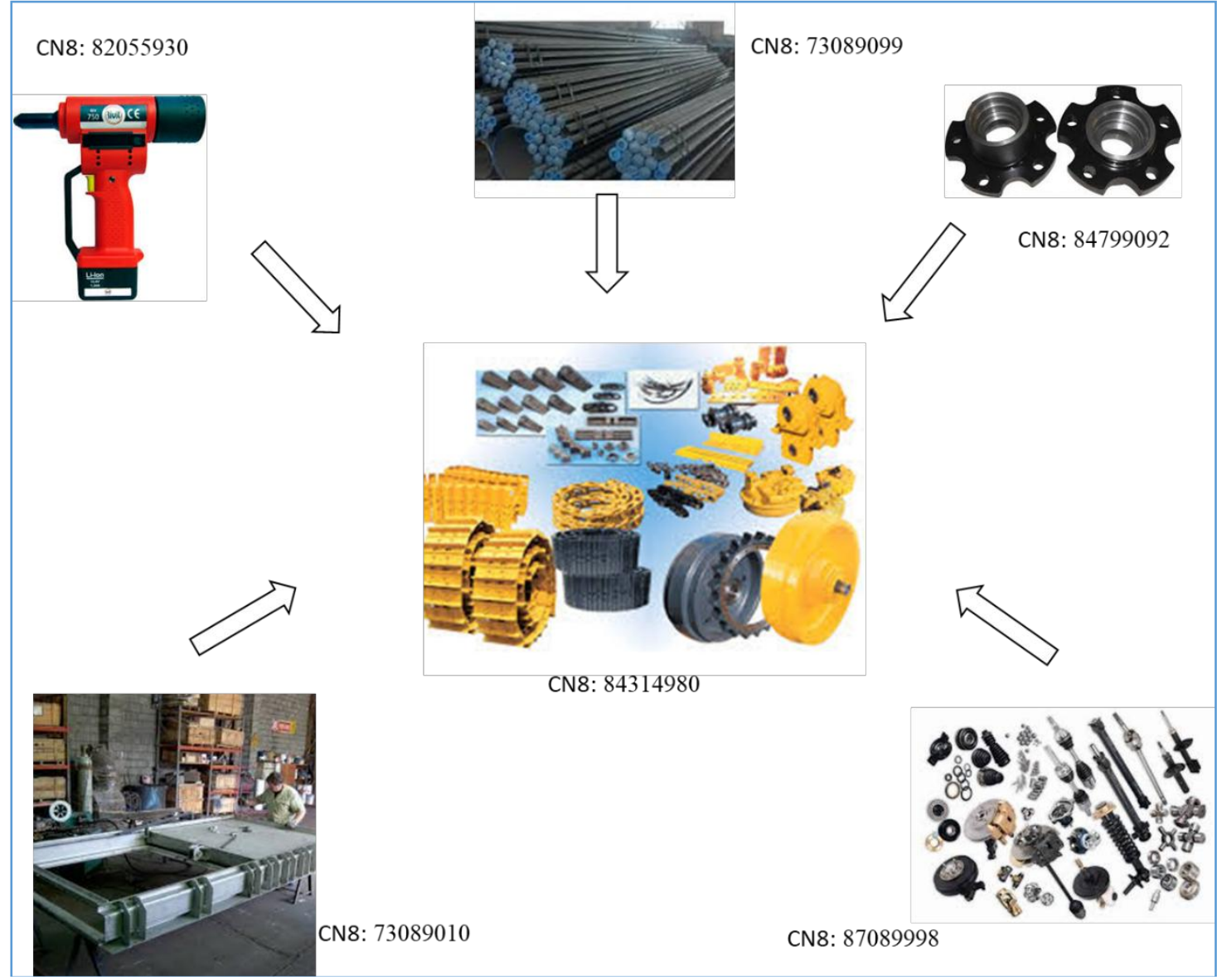

Note: the picture provides an example of the category of products represented by each $\mathrm{Cn} 8$-code. The products with the arrows on the corners of the figure indicate the most common exported products in 2005 among the firms that introduced the product CN8: 84314980 - in the centre of the figure- for the first time in 2006 (i.e. as new exported products) 
Figure 2. Distribution of new exported and imported products (2002-2012)

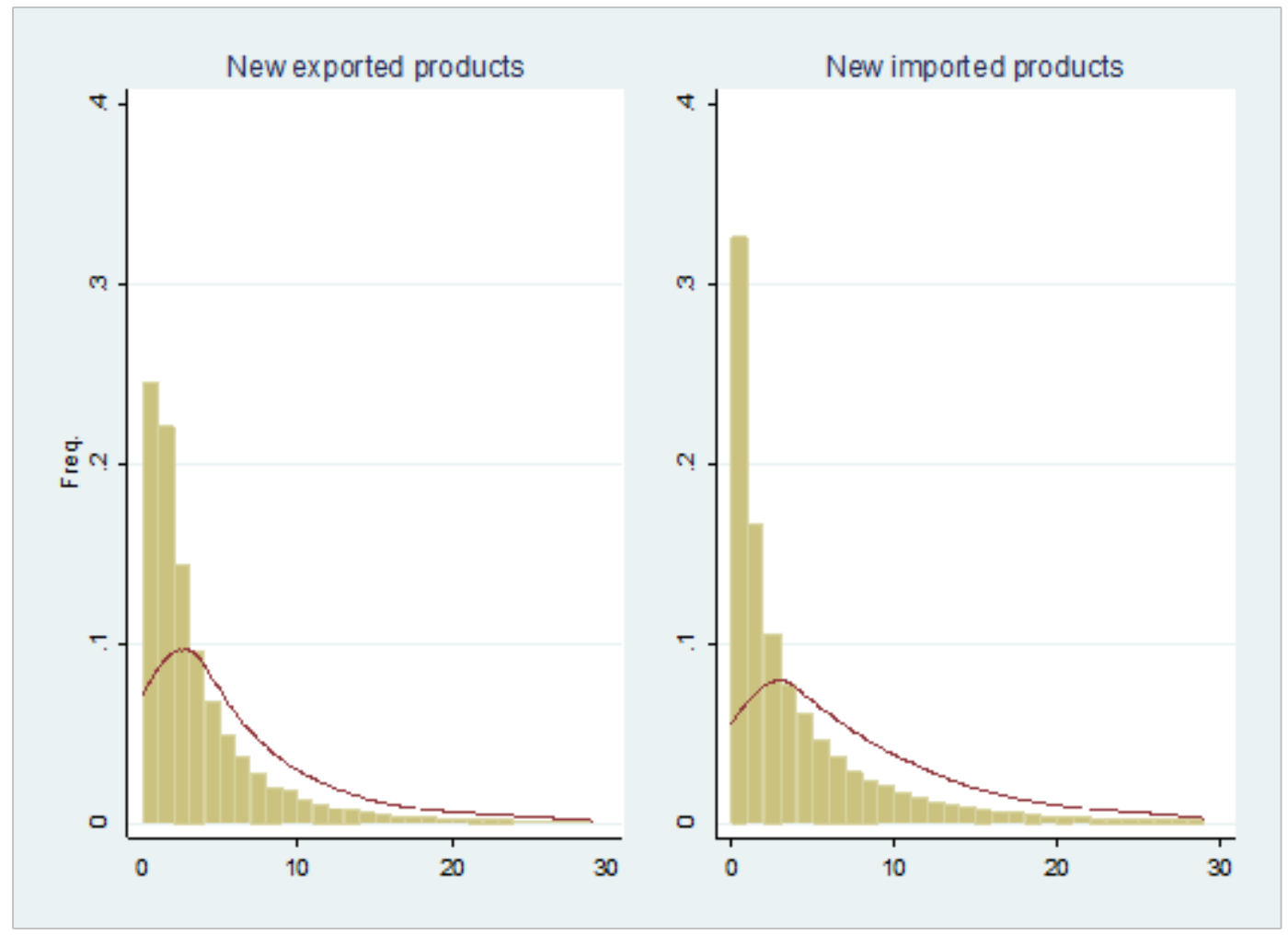

Figure 3 Distribution of new exported and imported products by size (2002-2012)
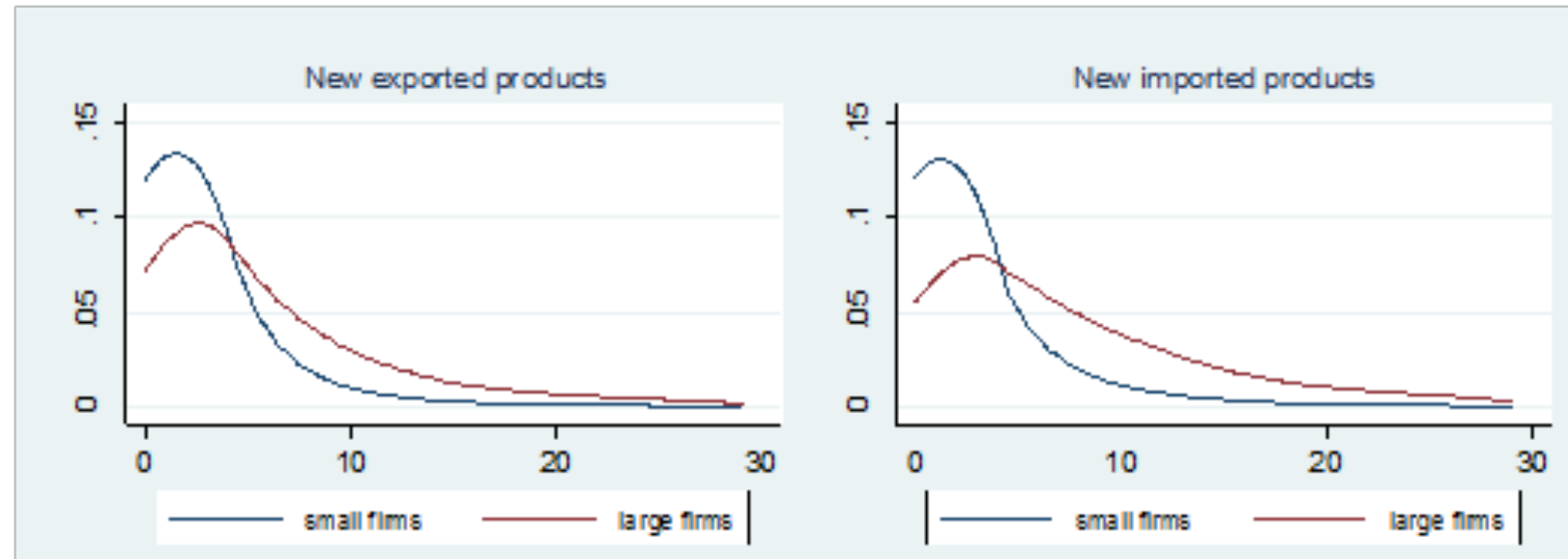
Figure 4. Robustness check: persistence of export.

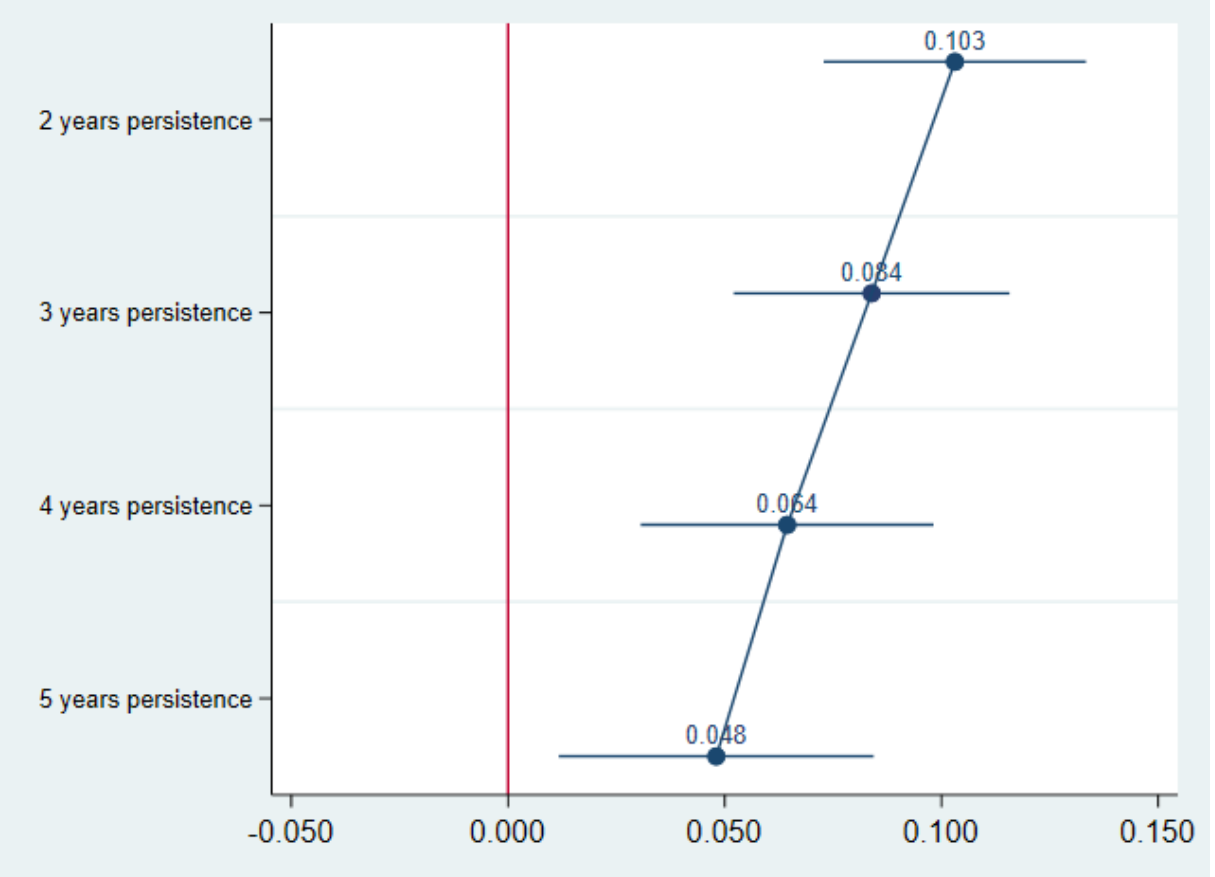

Notes: horizontal bars indicate $95 \%$ confidence intervals of the estimated coefficients 
Table 1. Variables description

\section{Variable}

\section{Description}

\section{Dependent variable}

$X$ NEW

X_NEW dummy

Independent variables

Importing and exporting activities In(IM_NEW)

IM_NEW dummy

In(IM_NEW_intermediate goods)

In(IM_NEW_capital goods)

In(IM_NEW_final goods)

IMP (dummy)

In(IM_VAR)

IM_VAR dummy

In(IM_TOT)

In(IM_SOURCES)

In(X_TOT)

Ownership type

Independent firm (dummy)

Swedish group (dummy)

Swedish MNE (dummy)

foreign MNE (dummy)

\section{Firm-level controls}

In(Productivity)

In(Employment)

In(Investments)

Patents (dummy) number of different types of products (CN8 8-digits) exported for the first time by the firm in year $\mathrm{t}$

$=1$ if the firm introduced at least one type of products (CN8 8-digits) exported for the first time in year $\mathrm{t}$

$\log$ of the number of different types of products (CN8 8-digits) imported for the first time by the firm in year $\mathrm{t}^{*}$

$=1$ if the firm introduced at least one type of products (CN8 8-digits) imported for the first time in year $\mathrm{t}$

$\log$ of the number of different types of intermediate goods products (CN8 8-digits and BEC) imported for the first time by the firm in year $t^{*}$ $\log$ of the number of different types of capital goods products (CN8 8-digits and BEC) imported for the first time by the firm in year $t^{*}$

$\log$ of the number of different types of final goodsproducts (CN8 8-digits and BEC) imported for the first time by the firm in year $\mathrm{t}^{*}$

$=1$ if the firm is an importer at time $\mathrm{t}$

$\log$ of the number of new product-country combinations of imported products in year $t^{*}$

$=1$ if the firm introduced at least one new product-country combination of imported products in year $\mathrm{t}$

$\log$ of the sum of the different types of products imported in year $t^{*}$

$\log$ of the sum of all the product-country combinations of imported products in year $\mathrm{t}^{*}$

$\log$ of the sum of the different types of products exported in year $t^{*}$

$=1$ for a firm not belonging to a group

$=1$ for a firm belonging to a Swedish group

$=1$ for a firm belonging to a Swedish group with foreign subsidiaries

$=1$ for a firm belonging to a foreign group with Swedish subsidiaries

$\log$ of labor productivity (value added over number of employees)

$\log$ of the number of employees

$\log$ of the level of investments in machinery and equipment*

$=1$ for a firm having at least one employee who patented in year $\mathrm{t}$

* to avoid the log of zero, we add 1 before taking the $\ln$ 
Table 2. The composition of the sample

\begin{tabular}{|c|c|c|c|c|c|c|c|c|c|c|c|c|c|}
\hline \multicolumn{14}{|l|}{ Full sample } \\
\hline year & 2001 & 2002 & 2003 & 2004 & 2005 & 2006 & 2007 & 2008 & 2009 & 2010 & 2011 & 2012 & Total \\
\hline Domestic firms & 4,235 & 4,049 & 4,046 & 4,119 & 4,160 & 4,101 & 4,022 & 3,958 & 4,006 & 3,932 & 4,023 & 3,931 & 48,582 \\
\hline Only exporters & 1,545 & 1,557 & 1,545 & 1,557 & 1,593 & 1,546 & 1,555 & 1,538 & 1,552 & 1,545 & 1,379 & 1,345 & 18,257 \\
\hline Only importers & 814 & 793 & 794 & 798 & 826 & 846 & 870 & 859 & 786 & 846 & 773 & 757 & 9,762 \\
\hline Two way traders & 4,788 & 4,930 & 4,926 & 4,866 & 4,697 & 4,740 & 4,749 & 4,748 & 4,510 & 4,392 & 4,357 & 4,244 & 55,947 \\
\hline Total by year & 11,382 & 11,329 & 11,311 & 11,340 & 11,276 & 11,233 & 11,196 & 11,103 & 10,854 & 10,715 & 10,532 & 10,277 & 132,548 \\
\hline \multicolumn{14}{|l|}{ Restricted sample } \\
\hline year & & 2002 & 2003 & 2004 & 2005 & 2006 & 2007 & 2008 & 2009 & 2010 & 2011 & 2012 & Total \\
\hline Only exporters & & 952 & 1,034 & 1,078 & 1,147 & 1,132 & 1,119 & 1,089 & 1,168 & 1,152 & 1,070 & 997 & 11,938 \\
\hline Two way traders & & 4,273 & 4,480 & 4,477 & 4,350 & 4,372 & 4,395 & 4,431 & 4,188 & 4,093 & 4,067 & 3,923 & 47,049 \\
\hline Total by year & & 5,225 & 5,514 & 5,555 & 5,497 & 5,504 & 5,514 & 5,520 & 5,356 & 58,987 & 5,137 & 4,920 & 58,987 \\
\hline
\end{tabular}


Table 3. Exported and imported new products

\begin{tabular}{lccc} 
restricted sample & All firms & Small firms & Large firms \\
& & & \\
\hline CN8-digits & & & \\
firms with new exported products & 44,601 & 30,410 & 14,191 \\
firms with new imported products & 40,024 & 25,581 & 14,443 \\
tot. number of firms & 58,987 & 42,911 & 16,076 \\
share firms with new exported products (\%) & 75.6 & 70.9 & 88.3 \\
share firms with new imported products (\%) & 67.9 & 59.6 & 89.8 \\
& & & \\
firms with new exported varieties & 50,316 & 34,942 & 15,374 \\
firms with new imported varieties & 42,638 & 27,639 & 14,999 \\
share firms with new exp. varieties (\%) & 85.3 & 81.4 & 95.6 \\
share firms with new imp. varieties (\%) & 72.3 & 64.4 & 93.3 \\
& & & \\
new exported products (mean) & 3.514 & 2.365 & 6.581 \\
new imported products (mean) & 4.126 & 2.377 & 8.794 \\
tot number of export types & 11.633 & 6.795 & 24.546 \\
tot number of import types & 15.253 & 7.291 & 36.506 \\
share of new exported products (\%) & 30.2 & 34.8 & 26.8 \\
share of new imported products (\%) & 27.0 & 32.6 & 24.1 \\
& & & \\
HS6-digits & & & \\
new exported products (mean) & 2.963 & 2.027 & 5.436 \\
new imported products (mean) & 3.463 & 2.036 & 7.235 \\
tot number of export types & 10.231 & 6.126 & 21.083 \\
tot number of import types & 13.486 & 6.617 & 31.649 \\
share of new exported products (\%) & 28.9 & 33.1 & 25.8 \\
share of new imported products (\%) & 30.8 & 22.9 \\
\hline
\end{tabular}


Table 4. Most common new exported products in 2006 among Swedish exporters.

\begin{tabular}{|c|c|c|c|c|c|}
\hline \multirow[b]{2}{*}{$\begin{array}{l}\text { freq. } \\
105\end{array}$} & \multirow[b]{2}{*}{$\begin{array}{l}\text { cn8 - code } \\
73089010\end{array}$} & \multirow[b]{2}{*}{$\begin{array}{l}\text { description } \\
\text { Weirs, sluices, lock-gates, } \\
\text { landing stages, fixed docks and } \\
\text { other maritime and waterway } \\
\text { structures, of iron or steel }\end{array}$} & \multicolumn{3}{|c|}{$\begin{array}{l}\text { Most common exported products in } 2005 \text { among the firms who introduced the new exported product to } \\
\text { the left in } 2006\end{array}$} \\
\hline & & & $\begin{array}{c}\text { freq. } \\
10 \\
10 \\
7 \\
7 \\
6\end{array}$ & $\begin{array}{l}\text { cn8 - code } \\
87089998 \\
84799092 \\
94032010 \\
84099900 \\
84314980 \\
\end{array}$ & $\begin{array}{l}\text { description } \\
\text { Parts and accessories for tractors, motor vehicles for the transport of ten or more persons, motor vehicles ... } \\
\text { Parts of machines and mechanical appliances having individual functions, of cast iron or cast steel, n.e.s. } \\
\text { Metal furniture, for civil aircraft (excl. for offices, seats and medical, surgical, dental or veterinary furniture) } \\
\text { Parts suitable for use solely or principally with compression-ignition internal combustion piston engine, n.e.s. } \\
\text { Parts of machinery of heading } 8426,8429 \text { and } 8430 \text {, n.e.s. }\end{array}$ \\
\hline 101 & 84314980 & $\begin{array}{l}\text { Parts of machinery for ships' } \\
\text { derricks, self-propelled } \\
\text { bulldozers, angledozers, levellers, } \\
\text { excavators and other moving, } \\
\text { levelling, scraping or excavating } \\
\text { machinery. }\end{array}$ & $\begin{array}{l}23 \\
12 \\
9 \\
9 \\
8\end{array}$ & $\begin{array}{l}84799092 \\
87089998 \\
73089010 \\
73089099 \\
82055930\end{array}$ & $\begin{array}{l}\text { Parts of machines and mechanical appliances having individual functions, of cast iron or cast steel, n.e.s. } \\
\text { Parts and accessories for tractors, motor vehicles for the transport of ten or more persons, motor vehicles ... } \\
\text { Weirs, sluices, lock-gates, landing stages, fixed docks and other waterway structures, of iron or steel } \\
\text { Structures and parts of structures of iron or steel, n.e.s. (excl. bridges and bridge-sections } \\
\text { Cartridge-operated riveting, wallplugging, etc., hand tools }\end{array}$ \\
\hline 77 & 87089998 & $\begin{array}{l}\text { Parts and accessories for tractors, } \\
\text { motor vehicles for the transport } \\
\text { of ten or more persons, motor } \\
\text { cars and other motor vehicles for } \\
\text { the transport of persons and } \\
\text { goods, special purpose motor } \\
\text { vehicles. }\end{array}$ & $\begin{array}{l}10 \\
9 \\
9 \\
8 \\
7 \\
7\end{array}$ & $\begin{array}{l}85364900 \\
84859080 \\
84139110 \\
84798991 \\
84099900 \\
85369010\end{array}$ & $\begin{array}{l}\text { Relays for a voltage }>60 \mathrm{~V} \text { but }<=1.000 \mathrm{~V} \\
\text { Machinery parts of chapter } 84 \text {, not intended for a specific purpose, n.e.s. } \\
\text { Parts of pumps for liquids, for civil aircraft, n.e.s. } \\
\text { Machines for glazing and decorating ceramic products } \\
\text { Parts suitable for use solely or principally with compression-ignition internal combustion piston engine, n.e.s. } \\
\text { Connections and contact elements, for wire and cables, for a voltage of }<=1.000 \mathrm{~V}\end{array}$ \\
\hline 56 & 44219098 & Articles of wood, n.e.s. & $\begin{array}{l}7 \\
7 \\
7 \\
5 \\
5 \\
5\end{array}$ & $\begin{array}{l}94032010 \\
94032091 \\
94032099 \\
44189090 \\
44071091 \\
48211010\end{array}$ & $\begin{array}{l}\text { Metal furniture, for civil aircraft (excl. for offices, seats and medical, surgical, dental or veterinary furniture) } \\
\text { Metal beds (excl. for civil aircraft and hospital beds with mechanical fittings) } \\
\text { Metal furniture (excl. for civil aircraft, for offices, medical, surgical, dental or veterinary furniture, beds and } \\
\text { seats) } \\
\text { Builders' joinery and carpentry, of wood, incl. cellular wood panels, of wood } \\
\text { Spruce of the species "Picea abies Karst." or silver fir "Abies alba Mill." } \\
\text { Self-adhesive paper or paperboard labels of all kinds, printed }\end{array}$ \\
\hline 54 & 39261000 & $\begin{array}{l}\text { Office or school supplies, of } \\
\text { plastics, n.e.s. }\end{array}$ & $\begin{array}{l}7 \\
7 \\
6 \\
5 \\
5\end{array}$ & $\begin{array}{l}39231000 \\
85369010 \\
39069090 \\
39241000 \\
87089998\end{array}$ & $\begin{array}{l}\text { Boxes, cases, crates and similar articles for the conveyance or packaging of goods, of plastics } \\
\text { Connections and contact elements, for wire and cables, for a voltage of }<=1.000 \mathrm{~V} \\
\text { Acrylic polymers in primary forms } \\
\text { Tableware and kitchenware, of plastics } \\
\text { Parts and accessories for tractors, motor vehicles for the transport of ten or more persons, motor vehicle... }\end{array}$ \\
\hline
\end{tabular}


Table 5. Descriptive statistics

\begin{tabular}{lccccc}
\hline Variable & Obs & Mean & Std. Dev. & Min & Max \\
\hline X_NEW & 58987 & 3.514 & 6.360 & 0 & 293 \\
X_NEW (dummy) & 58987 & 0.786 & 0.410 & 0 & 1 \\
IMP(dummy) & 58987 & 0.797 & 0.402 & 0 & 1 \\
In(TOT_X) & 58987 & 1.725 & 1.122 & 0 & 6.395 \\
In(IM_NEW) & 58987 & 1.120 & 1.002 & 0 & 5.771 \\
IM_NEW dummy & 58987 & 0.689 & 0.463 & 0 & 1 \\
In(IM_NEW_intermediate goods) & 58987 & 0.872 & 0.885 & 0 & 5.459 \\
In(IM_NEW_capital goods) & 58987 & 0.378 & 0.596 & 0 & 4.369 \\
In(IM_NEW_final goods) & 58987 & 0.311 & 0.561 & 0 & 4.488 \\
In(IM_VAR) & 58987 & 1.444 & 1.237 & 0 & 7.227 \\
IM_VAR dummy & 58987 & 0.729 & 0.444 & 0 & 1 \\
In(TOT_IM) & 58987 & 1.829 & 1.365 & 0 & 6.553 \\
In(TOT_SOURCES) & 58987 & 2.052 & 1.554 & 0 & 7.963 \\
In(Productivity) & 58987 & 13.203 & 0.511 & 6.236 & 20.036 \\
In(Employment) & 58987 & 3.294 & 1.286 & 0 & 10.057 \\
In(Investments) & 58987 & 14.535 & 2.680 & 0 & 23.658 \\
Independent firm (dummy) & 58987 & 0.308 & 0.462 & 0 & 1 \\
Swedish group (dummy) & 58987 & 0.305 & 0.460 & 0 & 1 \\
Swedish MNE (dummy) & 58987 & 0.212 & 0.409 & 0 & 1 \\
Foreign MNE (dummy) & 58987 & 0.174 & 0.380 & 0 & 1 \\
Patents (dummy) & 58987 & 0.046 & 0.209 & 0 & 1 \\
\hline
\end{tabular}




\begin{tabular}{|c|c|c|c|c|c|c|}
\hline & $\begin{array}{c}\text { (1) } \\
\text { all firms }\end{array}$ & $\begin{array}{c}\text { (2) } \\
\text { all firms }\end{array}$ & $\begin{array}{l}\text { (3) } \\
\text { all firms }\end{array}$ & $\begin{array}{c}\text { (4) } \\
\text { all firms }\end{array}$ & $\begin{array}{l}\text { (5) } \\
\text { all firms }\end{array}$ & $\begin{array}{c}\text { (6) } \\
\text { all firms }\end{array}$ \\
\hline \multirow[t]{2}{*}{$\mathrm{IMP}_{\mathrm{it}-1}$ (dummy) } & - & $0.043^{* *}$ & $-0.039 * *$ & $-0.047^{* * *}$ & 0.003 & 0.029 \\
\hline & - & $(0.017)$ & $(0.018)$ & $(0.018)$ & $(0.020)$ & $(0.020)$ \\
\hline \multirow[t]{2}{*}{$\ln \left(I M \_N E W\right)_{i t-1}$} & - & - & $0.100^{* * *}$ & $0.073^{* * *}$ & $0.103^{* * *}$ & - \\
\hline & - & - & $(0.007)$ & $(0.013)$ & $(0.015)$ & - \\
\hline \multirow[t]{2}{*}{ In(IM_NEW_intermediate goods) it-1 $_{\text {-1 }}$} & - & - & - & - & - & $0.070^{* * *}$ \\
\hline & - & - & - & - & - & $(0.011)$ \\
\hline \multirow{2}{*}{$\ln \left(I M \_N E W \_c a p i t a l \text { goods }\right)_{i t-1}$} & - & - & - & - & - & $0.039 * * *$ \\
\hline & - & - & - & - & - & $(0.009)$ \\
\hline \multirow{2}{*}{ In(IM_NEW_final goods) it-1 } & - & - & - & - & - & $0.046^{* * *}$ \\
\hline & - & - & - & - & - & $(0.009)$ \\
\hline \multirow{2}{*}{$\ln \left(I M \_V A R\right)_{\text {it-1 }}$} & - & - & - & $0.032^{* *}$ & $0.052 * * *$ & $0.057^{* * *}$ \\
\hline & - & - & - & $(0.013)$ & $(0.018)$ & $(0.016)$ \\
\hline \multirow[t]{2}{*}{$\ln \left(T O T \_I M\right)_{i t-1}$} & - & - & - & - & $-0.146^{* * *}$ & $-0.139 * * *$ \\
\hline & - & - & - & - & $(0.032)$ & $(0.030)$ \\
\hline \multirow[t]{2}{*}{$\ln (\text { TOT_SOURCES })_{\mathrm{it}-1}$} & - & - & - & - & $0.063^{* *}$ & $0.056^{* *}$ \\
\hline & - & - & - & - & $(0.030)$ & $(0.028)$ \\
\hline \multirow[t]{2}{*}{$\ln \left(T_{0} X_{-}\right)_{\text {it-1 }}$} & $0.162^{* * *}$ & $0.161^{* * *}$ & $0.140^{* * *}$ & $0.138^{* * *}$ & $0.145^{* * *}$ & $0.143^{* * *}$ \\
\hline & $(0.007)$ & $(0.007)$ & $(0.007)$ & $(0.007)$ & $(0.007)$ & $(0.007)$ \\
\hline \multirow[t]{2}{*}{ Patents $_{\text {it-1 }}$ (dummy) } & $0.032^{*}$ & $0.032^{*}$ & 0.026 & 0.025 & 0.025 & 0.021 \\
\hline & (0.018) & (0.018) & $(0.017)$ & $(0.017)$ & $(0.017)$ & $(0.017)$ \\
\hline \multirow[t]{2}{*}{$\ln \left(\right.$ Productivity) ${ }_{\text {it-1 }}$} & $0.044^{* * *}$ & $0.043^{* * *}$ & $0.037^{* * *}$ & $0.035^{* * *}$ & $0.040^{* * *}$ & $0.039^{* * *}$ \\
\hline & $(0.010)$ & $(0.010)$ & $(0.010)$ & $(0.010)$ & $(0.010)$ & $(0.010)$ \\
\hline \multirow[t]{2}{*}{$\ln (\text { Employment })_{\text {it }-1}$} & $0.084^{* * *}$ & $0.083^{* * *}$ & $0.060 * * *$ & $0.057^{* * *}$ & $0.066 * * *$ & $0.063^{* * *}$ \\
\hline & $(0.008)$ & $(0.008)$ & $(0.008)$ & $(0.009)$ & $(0.009)$ & $(0.009)$ \\
\hline \multirow[t]{2}{*}{$\ln (\operatorname{lnvestments})_{\mathrm{it}-1}$} & $0.010^{* * *}$ & $0.009^{* * *}$ & $0.009 * * *$ & $0.009^{* * *}$ & $0.009^{* * *}$ & $0.009^{* * *}$ \\
\hline & $(0.003)$ & $(0.003)$ & $(0.003)$ & (0.003) & $(0.003)$ & (0.003) \\
\hline \multirow{2}{*}{\multicolumn{7}{|c|}{$\begin{array}{l}\text { Ownership type } \\
\text { reference: independ. Firms }\end{array}$}} \\
\hline & & & & & & \\
\hline \multirow[t]{2}{*}{ Swedish group ${ }_{i t-1}$} & 0.011 & 0.010 & 0.008 & 0.008 & 0.007 & 0.006 \\
\hline & (0.018) & $(0.018)$ & $(0.018)$ & $(0.018)$ & $(0.018)$ & $(0.018)$ \\
\hline \multirow[t]{2}{*}{ Swedish $\mathrm{MNE}_{\mathrm{it}-1}$} & 0.015 & 0.013 & 0.007 & 0.005 & 0.008 & 0.007 \\
\hline & $(0.021)$ & $(0.021)$ & $(0.021)$ & $(0.021)$ & $(0.021)$ & $(0.021)$ \\
\hline \multirow[t]{2}{*}{ Foreign $\mathrm{MNE}_{\mathrm{it}-1}$} & -0.036 & $-0.038^{*}$ & $-0.051^{* *}$ & $-0.054^{* *}$ & $-0.043^{*}$ & $-0.044^{*}$ \\
\hline & $(0.023)$ & $(0.023)$ & $(0.023)$ & $(0.023)$ & $(0.023)$ & $(0.023)$ \\
\hline Time dummies & YES & YES & YES & YES & YES & YES \\
\hline Firm fixed effects & YES & YES & YES & YES & YES & YES \\
\hline \multirow[t]{2}{*}{ Constant } & $-0.553^{* * *}$ & $-0.570^{* * *}$ & $-0.403^{* * *}$ & $-0.376^{* * *}$ & $-0.430^{* * *}$ & $-0.406^{* * *}$ \\
\hline & $(0.141)$ & $(0.141)$ & $(0.140)$ & $(0.140)$ & $(0.141)$ & $(0.141)$ \\
\hline Observations & 58,987 & 58,987 & 58,987 & 58,987 & 58,987 & 58,987 \\
\hline Number of firms & 7,497 & 7,497 & 7,497 & 7,497 & 7,497 & 7,497 \\
\hline
\end{tabular}


Table 7. The determinants of new exported products, by firm size

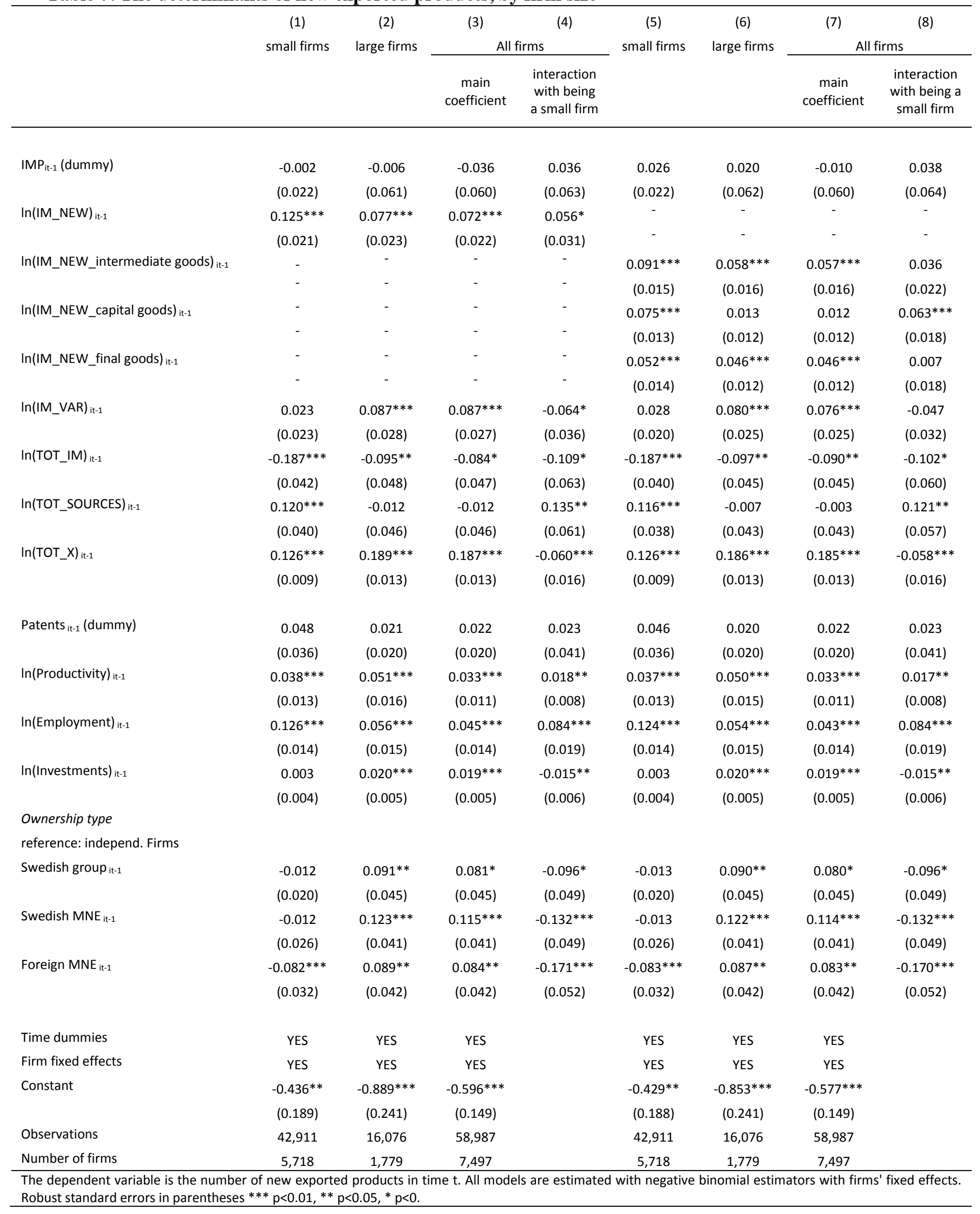


Table 8. Robustness checks: different product categories and excluding carry along trade

\begin{tabular}{|c|c|c|c|c|c|c|}
\hline & (1) & $(2)$ & (3) & (4) & (5) & (6) \\
\hline & \multicolumn{3}{|c|}{ HS6-digits } & \multicolumn{3}{|c|}{ No carry-along trade } \\
\hline & All firms & Small firms & Large firms & All firms & Small firms & Large firms \\
\hline $\mathrm{IMP}_{\mathrm{it}-1}$ (dummy) & $\begin{array}{l}-0.001 \\
(0.021)\end{array}$ & $\begin{array}{l}-0.001 \\
(0.023)\end{array}$ & $\begin{array}{l}-0.066 \\
(0.064)\end{array}$ & $\begin{array}{l}-0.012 \\
(0.019)\end{array}$ & $\begin{array}{l}-0.025 \\
(0.021)\end{array}$ & $\begin{array}{c}0.001 \\
(0.056)\end{array}$ \\
\hline $\ln \left(I M \_N E W\right)_{i t-1}$ & $\begin{array}{c}0.101^{* * *} \\
(0.015)\end{array}$ & $\begin{array}{c}0.115^{* * *} \\
(0.021)\end{array}$ & $\begin{array}{c}0.083^{* * *} \\
(0.022)\end{array}$ & $\begin{array}{c}0.085^{* * *} \\
(0.017)\end{array}$ & $\begin{array}{c}0.095^{* * *} \\
(0.023)\end{array}$ & $\begin{array}{c}0.067^{* * *} \\
(0.025)\end{array}$ \\
\hline $\ln \left(I M \_V A R\right)_{\text {it-1 }}$ & $\begin{array}{c}0.053^{* * *} \\
(0.017)\end{array}$ & $\begin{array}{c}0.028 \\
(0.023)\end{array}$ & $\begin{array}{c}0.084^{* * *} \\
(0.027)\end{array}$ & $\begin{array}{c}0.045^{* *} \\
(0.020)\end{array}$ & $\begin{array}{c}0.026 \\
(0.026)\end{array}$ & $\begin{array}{c}0.072^{* *} \\
(0.031)\end{array}$ \\
\hline $\ln \left(T O T \_I M\right)_{i t-1}$ & $\begin{array}{c}-0.137^{* * *} \\
(0.031)\end{array}$ & $\begin{array}{c}-0.170 * * * \\
(0.042)\end{array}$ & $\begin{array}{c}-0.094 * * \\
(0.048)\end{array}$ & $\begin{array}{c}-0.098^{* * *} \\
(0.038)\end{array}$ & $\begin{array}{c}-0.101 * * \\
(0.050)\end{array}$ & $\begin{array}{l}-0.081 \\
(0.060)\end{array}$ \\
\hline In(TOT_SOURCES) it-1 $_{\text {I }}$ & $\begin{array}{c}0.058^{* *} \\
(0.029)\end{array}$ & $\begin{array}{c}0.111^{* * *} \\
(0.039)\end{array}$ & $\begin{array}{l}-0.013 \\
(0.045)\end{array}$ & $\begin{array}{c}0.045 \\
(0.036)\end{array}$ & $\begin{array}{c}0.071 \\
(0.047)\end{array}$ & $\begin{array}{c}0.002 \\
(0.057)\end{array}$ \\
\hline $\ln (\text { TOT_X) })_{\text {it-1 }}$ & $\begin{array}{c}0.123^{* * *} \\
(0.008)\end{array}$ & $\begin{array}{c}0.103^{* * *} \\
(0.009)\end{array}$ & $\begin{array}{c}0.169^{* * *} \\
(0.014)\end{array}$ & $\begin{array}{c}0.152^{* * *} \\
(0.007)\end{array}$ & $\begin{array}{c}0.135^{* * *} \\
(0.009)\end{array}$ & $\begin{array}{c}0.192^{* * *} \\
(0.012)\end{array}$ \\
\hline Patents it-1 (dummy) & $\begin{array}{c}0.029 \\
(0.018)\end{array}$ & $\begin{array}{c}0.050 \\
(0.038)\end{array}$ & $\begin{array}{c}0.024 \\
(0.021)\end{array}$ & $\begin{array}{c}0.022 \\
(0.018)\end{array}$ & $\begin{array}{c}0.047 \\
(0.036)\end{array}$ & $\begin{array}{c}0.017 \\
(0.020)\end{array}$ \\
\hline $\ln (\text { Productivity })_{\text {it-1 }}$ & $\begin{array}{c}0.037^{* * *} \\
(0.010)\end{array}$ & $\begin{array}{c}0.032^{* *} \\
(0.014)\end{array}$ & $\begin{array}{c}0.055^{* * *} \\
(0.016)\end{array}$ & $\begin{array}{c}0.038^{* * *} \\
(0.010)\end{array}$ & $\begin{array}{c}0.039 * * * \\
(0.013)\end{array}$ & $\begin{array}{c}0.050^{* * *} \\
(0.016)\end{array}$ \\
\hline $\ln (\text { Employment })_{\mathrm{it}-1}$ & $\begin{array}{c}0.080 * * * \\
(0.009)\end{array}$ & $\begin{array}{c}0.134^{* * *} \\
(0.015)\end{array}$ & $\begin{array}{c}0.075^{* * *} \\
(0.015)\end{array}$ & $\begin{array}{c}0.069 * * * \\
(0.009)\end{array}$ & $\begin{array}{c}0.130 * * * \\
(0.014)\end{array}$ & $\begin{array}{c}0.065^{* * *} \\
(0.014)\end{array}$ \\
\hline $\ln (\text { Investments })_{\text {it-1 }}$ & $\begin{array}{c}0.009 * * * \\
(0.003)\end{array}$ & $\begin{array}{c}0.002 \\
(0.004)\end{array}$ & $\begin{array}{c}0.020^{* * *} \\
(0.005)\end{array}$ & $\begin{array}{c}0.009 * * * \\
(0.003)\end{array}$ & $\begin{array}{c}0.002 \\
(0.004)\end{array}$ & $\begin{array}{c}0.021^{* * *} \\
(0.005)\end{array}$ \\
\hline $\begin{array}{l}\text { Ownership type } \\
\text { reference: independ. }\end{array}$ & & & & & & \\
\hline Swedish group $_{\mathrm{it}-1}$ & $\begin{array}{c}0.007 \\
(0.019)\end{array}$ & $\begin{array}{l}-0.013 \\
(0.021)\end{array}$ & $\begin{array}{l}0.103^{* *} \\
(0.047)\end{array}$ & $\begin{array}{c}0.014 \\
(0.018)\end{array}$ & $\begin{array}{l}-0.009 \\
(0.020)\end{array}$ & $\begin{array}{c}0.123^{* * *} \\
(0.046)\end{array}$ \\
\hline Swedish $\mathrm{MNE}_{\mathrm{it}-1}$ & $\begin{array}{c}0.005 \\
(0.022)\end{array}$ & $\begin{array}{l}-0.013 \\
(0.028)\end{array}$ & $\begin{array}{c}0.128^{* * *} \\
(0.043)\end{array}$ & $\begin{array}{c}0.012 \\
(0.021)\end{array}$ & $\begin{array}{l}-0.013 \\
(0.026)\end{array}$ & $\begin{array}{c}0.154^{* * *} \\
(0.042)\end{array}$ \\
\hline Foreign $\mathrm{MNE}_{\mathrm{it}-1}$ & $\begin{array}{l}-0.032 \\
(0.024)\end{array}$ & $\begin{array}{c}-0.080 * * \\
(0.033)\end{array}$ & $\begin{array}{c}0.115^{* * *} \\
(0.044)\end{array}$ & $\begin{array}{l}-0.036 \\
(0.023)\end{array}$ & $\begin{array}{c}-0.073 * * \\
(0.032)\end{array}$ & $\begin{array}{c}0.122^{* * *} \\
(0.042)\end{array}$ \\
\hline Time dummies & YES & YES & YES & YES & YES & YES \\
\hline Firm fixed effects & YES & YES & YES & YES & YES & YES \\
\hline Constant & $\begin{array}{c}-0.384 * * * \\
(0.148)\end{array}$ & $\begin{array}{l}-0.333^{*} \\
(0.198)\end{array}$ & $\begin{array}{c}-0.912 * * * \\
(0.251)\end{array}$ & $\begin{array}{c}-0.433^{* * *} \\
(0.141)\end{array}$ & $\begin{array}{c}-0.472 * * \\
(0.190)\end{array}$ & $\begin{array}{c}-0.999 * * * \\
(0.240)\end{array}$ \\
\hline Observations & 58,900 & 42,737 & 16,163 & 58,536 & 42,415 & 16,121 \\
\hline Number of firms & 7,444 & 5,663 & 1,781 & 7,457 & 5,677 & 1,780 \\
\hline
\end{tabular}


Table 9. Robustness checks: discrete changes in new exported and imported products

\begin{tabular}{|c|c|c|c|c|c|c|c|c|c|}
\hline & $\begin{array}{c}\text { (1) } \\
\text { all firms }\end{array}$ & $\begin{array}{c}\text { (2) } \\
\text { small firms }\end{array}$ & $\begin{array}{c}(3) \\
\text { large }\end{array}$ & $\begin{array}{c}\text { (4) } \\
\text { all firms }\end{array}$ & $\begin{array}{c}(5) \\
\text { small }\end{array}$ & $\begin{array}{c}(6) \\
\text { large }\end{array}$ & $\begin{array}{c}\text { (7) } \\
\text { all firms }\end{array}$ & $\begin{array}{c}\text { (8) } \\
\text { small }\end{array}$ & $\begin{array}{c}(9) \\
\text { large }\end{array}$ \\
\hline & \multicolumn{3}{|c|}{ new exported products (dummy) } & \multicolumn{3}{|c|}{ new exported products (dummy) } & \multicolumn{3}{|c|}{ new exported products } \\
\hline \multirow[t]{2}{*}{$\mathrm{IMP}_{\mathrm{it}-1}$ (dummy) } & -0.051 & -0.033 & -0.236 & $-0.202^{* * *}$ & $-0.176^{* * *}$ & $-0.462^{* *}$ & $-0.096 * * *$ & $-0.097^{* * *}$ & -0.094 \\
\hline & $(0.051)$ & $(0.054)$ & $(0.168)$ & $(0.057)$ & $(0.061)$ & $(0.188)$ & $(0.025)$ & $(0.027)$ & $(0.077)$ \\
\hline \multirow[t]{2}{*}{$\ln \left(I M \_N E W\right)_{\text {it-1 }}$} & 0.072 & 0.101 & -0.045 & - & - & - & - & - & - \\
\hline & $(0.055)$ & $(0.063)$ & $(0.114)$ & - & - & - & - & - & - \\
\hline \multirow[t]{2}{*}{ IM_NEW dummy it-1 } & - & - & - & 0.028 & 0.076 & $-0.243^{*}$ & 0.028 & 0.037 & 0.009 \\
\hline & - & - & - & $(0.058)$ & $(0.064)$ & $(0.144)$ & $(0.022)$ & $(0.026)$ & $(0.046)$ \\
\hline \multirow[t]{2}{*}{$\ln \left(I M \_V A R\right)_{\text {it-1 }}$} & $0.154^{* * *}$ & $0.114^{*}$ & $0.279 * *$ & - & - & - & - & - & - \\
\hline & $(0.058)$ & $(0.066)$ & $(0.125)$ & - & - & - & - & - & - \\
\hline \multirow[t]{2}{*}{ IM_VAR dummy ${ }_{\text {it-1 }}$} & - & - & - & $0.141^{* *}$ & 0.108 & $0.368^{* *}$ & $0.062^{* *}$ & $0.066^{* *}$ & 0.025 \\
\hline & - & - & - & $(0.068)$ & $(0.073)$ & $(0.181)$ & (0.029) & $(0.032)$ & $(0.069)$ \\
\hline \multirow[t]{2}{*}{$\ln \left(\text { TOT_IM }_{-}\right)_{\mathrm{it}-1}$} & $-0.233^{* *}$ & $-0.229 *$ & -0.276 & -0.100 & -0.105 & -0.117 & 0.004 & -0.027 & 0.039 \\
\hline & $(0.114)$ & $(0.130)$ & $(0.241)$ & $(0.101)$ & $(0.116)$ & $(0.215)$ & $(0.027)$ & $(0.036)$ & $(0.040)$ \\
\hline \multirow[t]{2}{*}{$\ln \left(T_{O T} \text { SOURCES) }\right)_{\mathrm{it-1}}$} & $0.219^{* *}$ & $0.219^{*}$ & 0.293 & $0.265^{* * *}$ & $0.247^{* *}$ & $0.384^{*}$ & $0.045^{*}$ & $0.075^{* *}$ & 0.018 \\
\hline & $(0.105)$ & $(0.121)$ & $(0.221)$ & $(0.092)$ & $(0.105)$ & $(0.197)$ & $(0.024)$ & $(0.033)$ & $(0.037)$ \\
\hline \multirow[t]{2}{*}{$\ln \left(T O T \_X\right)_{i t-1}$} & $0.070^{* * *}$ & $0.064^{* * *}$ & 0.097 & $0.073^{* * *}$ & $0.066^{* * *}$ & $0.102^{*}$ & $0.143^{* * *}$ & $0.126^{* * *}$ & $0.181^{* * *}$ \\
\hline & $(0.022)$ & $(0.023)$ & $(0.060)$ & $(0.022)$ & $(0.023)$ & $(0.061)$ & $(0.007)$ & (0.009) & $(0.013)$ \\
\hline \multirow[t]{2}{*}{ Patents it-1 (dummy) } & 0.053 & 0.007 & 0.108 & 0.055 & 0.002 & 0.132 & $0.029^{*}$ & 0.053 & 0.023 \\
\hline & $(0.111)$ & (0.141) & $(0.182)$ & $(0.111)$ & $(0.141)$ & $(0.185)$ & $(0.018)$ & $(0.036)$ & $(0.020)$ \\
\hline \multirow[t]{2}{*}{$\ln$ (Productivity) $_{\text {it-1 }}$} & $0.108^{* * *}$ & $0.106^{* * *}$ & 0.087 & $0.103^{* * *}$ & $0.103^{* * *}$ & 0.080 & $0.033^{* * *}$ & $0.034^{* *}$ & $0.046 * * *$ \\
\hline & $(0.034)$ & $(0.038)$ & $(0.080)$ & $(0.034)$ & $(0.038)$ & $(0.082)$ & $(0.010)$ & $(0.013)$ & $(0.015)$ \\
\hline \multirow[t]{2}{*}{$\ln (\text { Employment })_{\text {it-1 }}$} & $0.323^{* * *}$ & $0.323^{* * *}$ & $0.279^{* * *}$ & $0.321^{* * *}$ & $0.320^{* * *}$ & $0.272^{* * *}$ & $0.068^{* * *}$ & $0.126^{* * *}$ & $0.065 * * *$ \\
\hline & $(0.036)$ & $(0.042)$ & $(0.071)$ & $(0.036)$ & $(0.042)$ & $(0.077)$ & $(0.009)$ & $(0.014)$ & $(0.014)$ \\
\hline \multirow[t]{2}{*}{$\ln \left(\right.$ Investments) ${ }_{\text {it-1 }}$} & 0.000 & 0.002 & -0.004 & 0.001 & 0.002 & -0.010 & $0.009 * * *$ & 0.003 & $0.020 * * *$ \\
\hline & $(0.008)$ & $(0.009)$ & $(0.019)$ & $(0.008)$ & $(0.009)$ & $(0.020)$ & $(0.003)$ & $(0.004)$ & $(0.005)$ \\
\hline
\end{tabular}




\section{Ownership type}

reference: independ. Firms

\begin{tabular}{|c|c|c|c|c|c|c|c|c|c|}
\hline \multirow[t]{2}{*}{ Swedish group $_{\text {it-1 }}$} & 0.052 & 0.040 & 0.067 & 0.055 & 0.041 & 0.030 & 0.014 & -0.010 & $0.116^{* * *}$ \\
\hline & $(0.055)$ & $(0.057)$ & (0.194) & $(0.055)$ & $(0.057)$ & (0.198) & $(0.018)$ & $(0.020)$ & $(0.045)$ \\
\hline \multirow[t]{2}{*}{ Swedish $\mathrm{MNE}_{\mathrm{it}-1}$} & $0.218^{* * *}$ & 0.110 & $0.573^{* * *}$ & $0.222^{* * *}$ & 0.111 & $0.518^{* *}$ & 0.006 & -0.019 & $0.141^{* * *}$ \\
\hline & $(0.080)$ & $(0.090)$ & $(0.200)$ & $(0.080)$ & $(0.090)$ & $(0.205)$ & $(0.021)$ & $(0.026)$ & $(0.041)$ \\
\hline \multirow[t]{2}{*}{ Foreign $\mathrm{MNE}_{\mathrm{it}-1}$} & -0.038 & -0.129 & 0.289 & -0.030 & -0.120 & 0.222 & $-0.051^{* *}$ & $-0.090 * * *$ & $0.104^{* *}$ \\
\hline & (0.096) & $(0.114)$ & $(0.204)$ & (0.096) & $(0.114)$ & $(0.212)$ & $(0.023)$ & $(0.032)$ & $(0.042)$ \\
\hline Time dummies & YES & YES & YES & YES & YES & YES & YES & YES & YES \\
\hline Firm fixed effects & YES & YES & YES & YES & YES & YES & YES & YES & YES \\
\hline \multirow[t]{2}{*}{ Constant } & - & - & - & - & - & - & $-0.432^{* * *}$ & $-0.451^{* *}$ & $-1.024^{* * *}$ \\
\hline & - & - & - & - & - & - & (0.141) & (0.188) & $(0.240)$ \\
\hline Observations & 42,172 & 34,490 & 7,682 & 42,172 & 34,490 & 7,514 & 59,247 & 43,066 & 16,181 \\
\hline Number of firms & 5,173 & 4,332 & 841 & 5,173 & 4,332 & 818 & 7,519 & 5,734 & 1,785 \\
\hline
\end{tabular}




\begin{tabular}{|c|c|c|c|c|c|c|}
\hline & (1) & (2) & (3) & (4) & (5) & (6) \\
\hline & All firms & Small firms & Large firms & All firms & Small firms & Large firms \\
\hline \multirow[t]{2}{*}{$\mathrm{IMP}_{\mathrm{it}-1}$ (dummy) } & 0.011 & 0.002 & 0.052 & -0.043 & -0.065 & 0.177 \\
\hline & $(0.054)$ & $(0.057)$ & $(0.208)$ & $(0.065)$ & $(0.068)$ & $(0.238)$ \\
\hline \multirow[t]{2}{*}{$\ln \left(I M \_N E W\right)_{\text {it-1 }}$} & 0.019 & -0.043 & 0.355 & & & \\
\hline & $(0.097)$ & $(0.105)$ & $(0.271)$ & & & \\
\hline \multirow[t]{2}{*}{ IM_NEW dummy ${ }_{\text {it-1 }}$} & & & & -0.057 & -0.082 & 0.082 \\
\hline & & & & (0.089) & $(0.094)$ & $(0.267)$ \\
\hline \multirow[t]{2}{*}{$\ln \left(I M \_V A R\right)_{\text {it-1 }}$} & 0.096 & 0.151 & -0.275 & & & \\
\hline & $(0.101)$ & $(0.108)$ & $(0.283)$ & & & \\
\hline \multirow[t]{2}{*}{ IM_VAR dummy it-1 } & & & & 0.110 & 0.154 & -0.306 \\
\hline & & & & $(0.096)$ & $(0.102)$ & $(0.300)$ \\
\hline \multirow[t]{2}{*}{$\ln \left(T O T \_I M\right)_{\text {it-1 }}$} & -0.164 & -0.110 & -0.503 & -0.076 & -0.072 & -0.164 \\
\hline & $(0.191)$ & $(0.205)$ & $(0.538)$ & $(0.170)$ & $(0.182)$ & $(0.485)$ \\
\hline \multirow[t]{2}{*}{$\ln \left(T O T \_S O U R C E S\right)_{i t-1}$} & $0.511 * * *$ & $0.471 * *$ & $0.821^{*}$ & $0.520 * * *$ & $0.524 * * *$ & 0.578 \\
\hline & $(0.178)$ & $(0.192)$ & $(0.491)$ & $(0.155)$ & $(0.166)$ & $(0.430)$ \\
\hline \multirow[t]{2}{*}{ Patents it-1 (dummy) } & 0.177 & 0.185 & 0.252 & 0.176 & 0.183 & 0.224 \\
\hline & (0.196) & $(0.214)$ & $(0.493)$ & (0.196) & $(0.214)$ & $(0.495)$ \\
\hline \multirow[t]{2}{*}{$\ln (\text { Productivity) })_{\text {it-1 }}$} & $0.255^{* * *}$ & $0.251^{* * *}$ & 0.204 & $0.254^{* * *}$ & $0.250 * * *$ & 0.206 \\
\hline & $(0.034)$ & $(0.035)$ & $(0.141)$ & $(0.034)$ & $(0.035)$ & $(0.140)$ \\
\hline \multirow[t]{2}{*}{ In(Employment) it-1 } & $0.717^{* * *}$ & $0.732^{* * *}$ & $0.496 * * *$ & $0.715^{* * *}$ & $0.730 * * *$ & $0.489 * * *$ \\
\hline & $(0.034)$ & $(0.035)$ & (0.129) & $(0.034)$ & $(0.035)$ & (0.129) \\
\hline \multirow[t]{2}{*}{$\ln (\text { Investments })_{\mathrm{it}-1}$} & $0.070 * * *$ & $0.063 * * *$ & $0.209 * * *$ & $0.070 * * *$ & $0.063 * * *$ & $0.212^{* * *}$ \\
\hline & $(0.008)$ & $(0.008)$ & $(0.048)$ & $(0.008)$ & $(0.008)$ & $(0.047)$ \\
\hline Ownership type & 0.000 & 0.000 & 0.000 & 0.000 & 0.000 & 0.000 \\
\hline reference: independ. Firms & $(0.000)$ & $(0.000)$ & $(0.000)$ & $(0.000)$ & $(0.000)$ & $(0.000)$ \\
\hline \multirow[t]{2}{*}{ Swedish group $_{\text {it-1 }}$} & 0.039 & 0.037 & -0.124 & 0.038 & 0.037 & -0.133 \\
\hline & $(0.053)$ & $(0.054)$ & (0.299) & $(0.053)$ & $(0.054)$ & (0.299) \\
\hline \multirow[t]{2}{*}{ Swedish MNE it-1 } & -0.079 & -0.041 & -0.338 & -0.080 & -0.041 & -0.352 \\
\hline & $(0.105)$ & $(0.112)$ & $(0.357)$ & $(0.105)$ & $(0.112)$ & $(0.357)$ \\
\hline \multirow[t]{2}{*}{ Foreign $\mathrm{MNE}_{\mathrm{it}-1}$} & $-0.274 * *$ & $-0.348 * *$ & 0.117 & $-0.277^{* *}$ & $-0.350 * *$ & 0.113 \\
\hline & $(0.131)$ & $(0.140)$ & $(0.432)$ & $(0.131)$ & $(0.140)$ & (0.429) \\
\hline Time dummies & YES & YES & YES & YES & YES & YES \\
\hline Firm fixed effects & YES & YES & YES & YES & YES & YES \\
\hline Observations & 41,839 & 39,448 & 2,391 & 41,839 & 39,448 & 2,391 \\
\hline Number of firms & 4,465 & 4,208 & 257 & 4,465 & 4,208 & 257 \\
\hline
\end{tabular}

The dependent variable is the probability to export in time t. All models are estimated with a logit estimator with fixed effects. Robust standard errors in parentheses $* * * \mathrm{p}<0.01, * * \mathrm{p}<0.05, * \mathrm{p}<0.1$ 